\title{
Microwave Irradiation in Technologies of Wastewater and Wastewater Sludge Treatment: A Review
}

\author{
Elena Vialkova *, Marina Obukhova and Larisa Belova (D) \\ Department of Water Supply and Sanitation, Industrial University of Tyumen, Volodarskogo Str., 38, \\ 625000 Tyumen, Russia; marina_tm@mail.ru (M.O.); klv.72@mail.ru (L.B.) \\ * Correspondence: vyalkova-e@yandex.ru; Tel.: +7-982-789-5364
}

Citation: Vialkova, E.; Obukhova, M.; Belova, L. Microwave Irradiation in Technologies of Wastewater and Wastewater Sludge Treatment: A Review. Water 2021, 13, 1784. https://doi.org/10.3390/w13131784

Academic Editor: Hongyu Ren

Received: 1 June 2021

Accepted: 25 June 2021

Published: 28 June 2021

Publisher's Note: MDPI stays neutral with regard to jurisdictional claims in published maps and institutional affiliations.

Copyright: (C) 2021 by the authors. Licensee MDPI, Basel, Switzerland. This article is an open access article distributed under the terms and conditions of the Creative Commons Attribution (CC BY) license (https:// creativecommons.org/licenses/by/ $4.0 /)$.

\begin{abstract}
Every year, the human impact on the world's water sources becomes more pronounced. One of the triggers to this increase is the use of ineffective wastewater and sludge treatment systems. Recently, the number of studies of microwave processing in handling liquid municipal and industrial waste has increased. This paper discusses heat treatment, change in properties, decomposition of substances, removal of metals, demulsification, pyrolysis, biogas processing, disinfection, and other topics. The findings of European, Chinese, Russian, and other authors are summarised and presented in this review. In addition, the most notable Russian patents for microwave installations/devices and reactors suitable for a wide variety of applications are discussed. In this article, the authors look at microwave wastewater and sludge treatment from the perspective of practical application in various fields of human economic activity.
\end{abstract}

Keywords: microwave irradiation (MW); wastewater (WW); wastewater/sewage sludge (WWS); treatment technology; MW installations/devices/reactors

\section{Introduction}

The size of global urban water consumption can be estimated based on the total population of Earth living in urban environments, which is more than 3.4 billion people, and the average water consumption per human of $499 \mathrm{~m}^{3}$ per year [1]. While accurate data on the amount of wastewater (WW) generated around the world is not available, using a calculated method based on the standard of water use and the percentage of irreversible losses (roughly 30-35 per cent) can help us assume that more than 1100 billion $\mathrm{m}^{3}$ of wastewater and $0.1-0.05 \%$ of that amount-wastewater sludge (WWS) - is treated and disposed of annually in urbanised settlements. Solving high-quality WW and WWS treatment issues leads to a decrease in the anthropogenic impact on water and land resources. New methods and technologies, such as electromagnetic microwave irradiation (MW), may help make a breakthrough in this field.

Microwave radiation is electromagnetic ultrahigh-frequency radiation, including decimeter, centimetre, and millimetre ranges of radio waves with a frequency of $0.3 \mathrm{GHz}$ to $300 \mathrm{GHz}$, corresponding to a wavelength from $1 \mathrm{~m}$ to $1 \mathrm{~mm}[2,3]$. High-intensity microwaves are commonly used for contactless heating of objects, including stoves for cooking food, metallurgical industry heat treatment installations, and medical devices for treating veins. People actively involve microwaves of a particular range (frequency from 1 to $100 \mathrm{GHz}$ ) in radiolocation. MW reactors are increasingly adopted to neutralise various solid and liquid wastes produced by people and industrial enterprises [4-6].

Microwave irradiation is confidently entering the wastewater (WW) and sludge (WWS) treatment technology in the twenty-first century, primarily as an alternative to conditional heating [4]. MW is a well-known heating and drying process used both for domestic and industrial purposes.

This method has several advantages over conventional electric heating, including non-contact heating, instant and rapid process with a high degree of uniformity, and precise 
heating, which induces dipolar oscillations and ionic conductivity in the medium [7,8]. In 2011, researchers conducted a comprehensive study of the existing state of MW technology for WW treatment [9]. According to this report, using MW to decompose contaminants has numerous advantages. For example, selectivity and reaction rate increase while reaction time, activation energy, equipment size, and waste parameters decrease.

These benefits are primarily due to the thermal and nonthermal effects of microwave irradiation. Many transformations with a beneficial impact on the structure and properties of water occur in the aquatic environment under the thermal influence of MW: increased dissolution of substances, coagulation and demulsification of pollution, activation of various chemical reactions (including oxidation of organic matter), and degradation of toxins; the disinfecting effect of MW is well known [10].

While the "thermal" effect of MW is well established and well understood for many environments, the "nonthermal" remains controversial [11,12]. Some researchers [13] believe that this type of physical impact can excite reactant molecules to higher vibrational and rotational energy levels, causing a weakening of the chemical bonds of polar molecules of substances. Thus, under the influence of MW, it comes out in the intensification of substance degradation. Various reviews and research articles have been published on specific issues using microwaves in WW and WWS treatment technologies. Table 1 shows the main directions of research in modern science on this topic.

Table 1. Key research directions on the use of MW in WW and WWS processing technologies.

\begin{tabular}{ccccc}
\hline Section & Direction of MW Research & WW & WWS & [Ref./No] \\
\hline Section 3.1 & Heating and thermal treatment & + & + & {$[3,9-27]$} \\
Section 3.2 & Properties change & + & + & {$[28-42]$} \\
Section 3.3 & Decontamination & + & + & {$[14,26,28,42-56]$} \\
Section 3.4 & Decomposition of organic substances & + & - & {$[9,13,22,57-81]$} \\
Section 3.5 & Demulsification & + & - & {$[82-90]$} \\
Section 3.6 & Extraction of heavy metals & + & + & {$[6,14,24,91,92]$} \\
Section 3.7 & Generation of biogas & - & + & {$[93-106]$} \\
Section 3.8 & Pyrolysis of sewage sludge & + & {$[107-109]$} \\
Section 3.9 & Sorbent modification & + & {$[73,110-119]$} \\
Section 3.10 & Devices for WW and WWS MW processing & + & + & {$[120-128]$} \\
\hline
\end{tabular}

This article provides an overview of microwave radiation used in WW and WWS treatment systems, and additional information. The experience of Russian scientists is included in the presented summary knowledge and world accomplishments, which consider MW from the standpoint of promising practical applications in economic and industrial human activities.

\section{Materials and Methods}

Searching for materials, the keywords "microwaves", "microwave irradiation", "wastewater", "wastewater/sewage sludge", and "MW installations, devices or reactors" were used to scan for thematic papers and patents in Web of Science, Scopus, Google Scholar, ELIBRARY.RU, and other outlets, without regard to publication date.

More than 120 publications related to wastewater and its sediments treatment by microwave radiation were selected to solve practical engineering and technological problems. Most of the considered articles were written in English (99 pieces) and just several in Russian (29 pieces). The search results were initially analysed regarding their abstract, followed by a thorough evaluation of their context when specific criteria were met. The information provided was collected between September 2020 and May 2021. Table 2 contains a summary of the sources used in the article. 
Table 2. Statistics of the sources used.

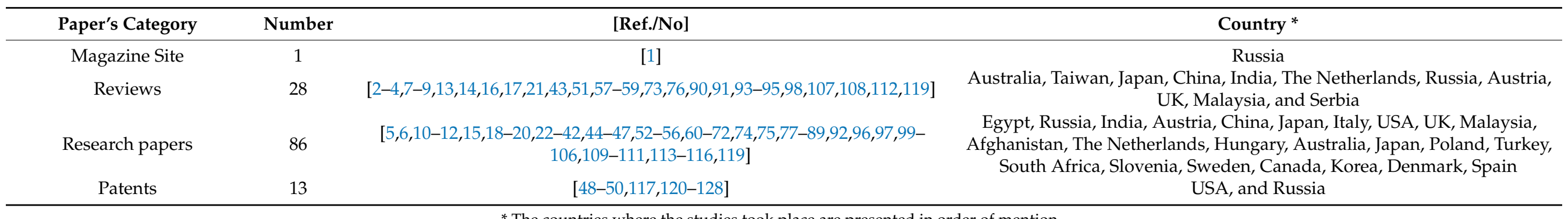

* The countries where the studies took place are presented in order of mention. 


\section{Results}

\subsection{Heating and Thermal Treatment}

MW has become increasingly common as a thermal method for treating wastewater and sediments in recent years, owing to its rapid and selective heating [9-15]. The thermal effect of MW [16] describes how ultrahigh-frequency energy can be consumed by microwave absorbers and dissipated as thermal energy. For many environments, including water solutions, microwave heating with dielectric losses is typical [13].

Water is a positive-charged molecule (or dipole) with a negative-charged opposite end. Dipolar polarization occurs due to intermolecular inertia, responsible for most of the microwave heating observed in liquids. The rapid change in the electric field of microwave radiation causes a rotation of dipoles. At the same time, the rate at which the dipole rotates (reverses) cannot accurately correlate to the rate at which the electric field shifts direction. It induces "internal friction" between water molecules, which leads to direct and very uniform heating of the reaction mixture. However, reflections and refractions at local boundaries between phases lead to the appearance of so-called "hot spots" and the effect of "overheating", which has been extensively discussed by researchers [15,17-21].

Figure 1 presents the schematic diagram of microwave action [3,17], illustrating the advantages and scope of application of microwave processing. Microwave heating penetrates the liquid and creates the rapidly changing field: dipoles (water molecules) continuously react attempting to align in the field, which generates heat; heat is uniformly distributed throughout the water.
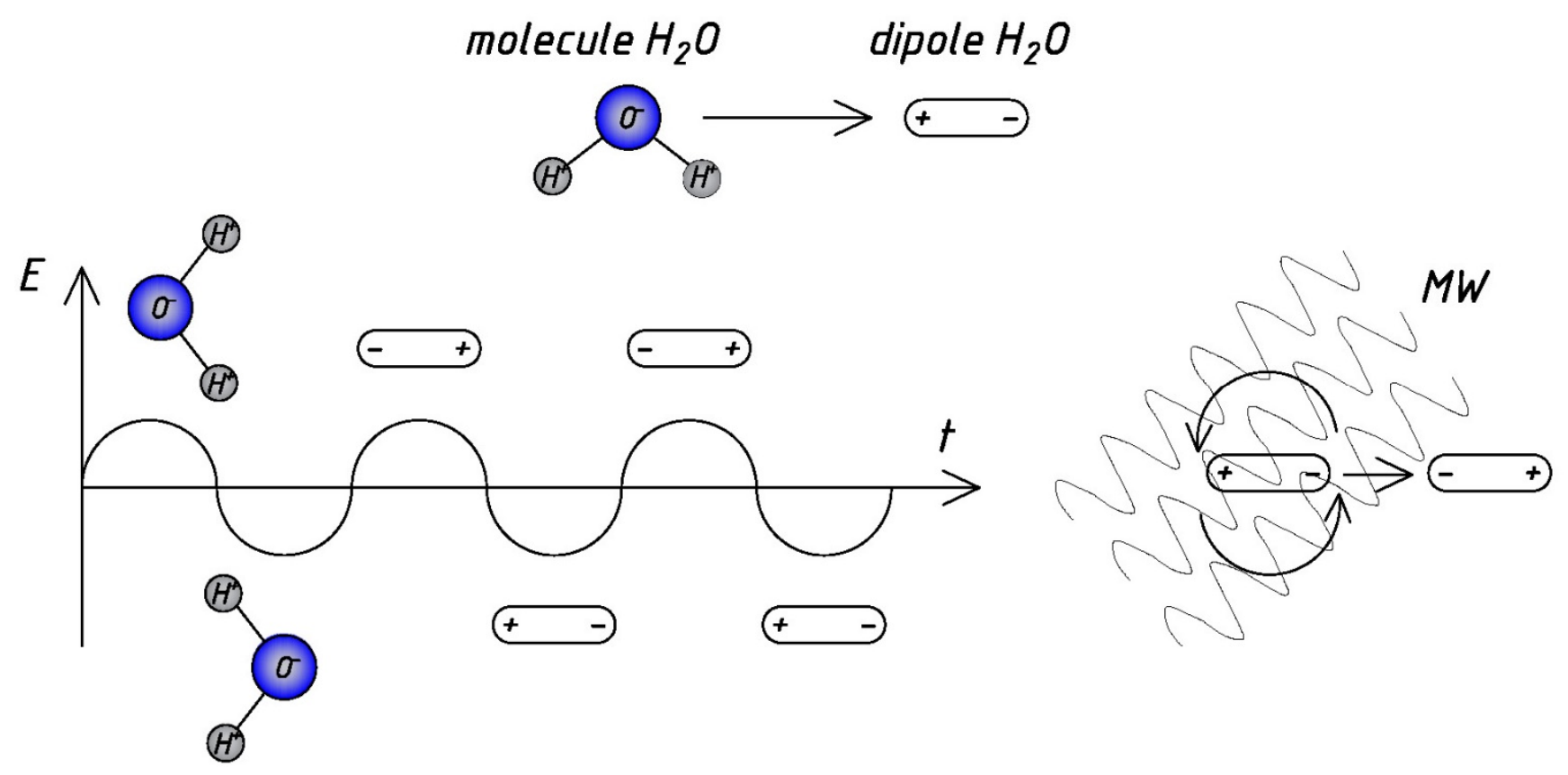

Figure 1. The scheme of mechanism of the MW water heating.

Under the influence of MW, several parameters such as strength, frequency, duration, treatment temperature, and sample volumes $[9,14,22-27]$ can influence the efficiency of pollutant decomposition and mineralisation of wastewater and sediments. It is confirmed in the materials [25-27], which use the Netherlands, Kenya, China, and other countries as examples of MW-heating of faecal sludge (Figure 2). 


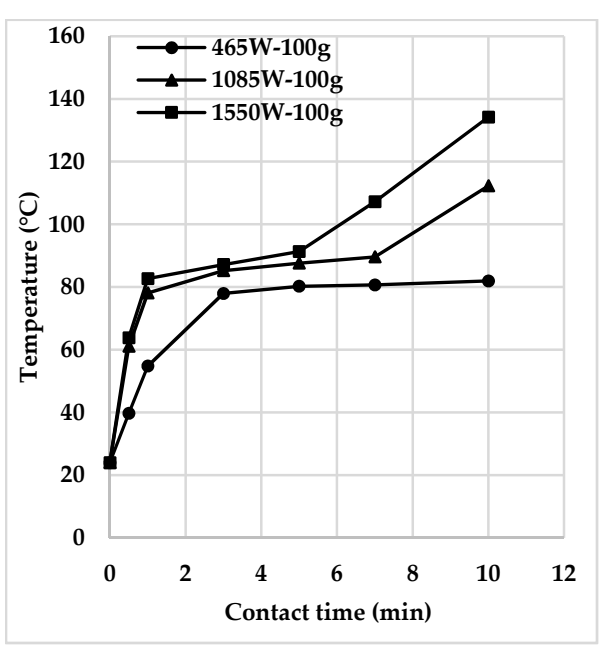

(a)

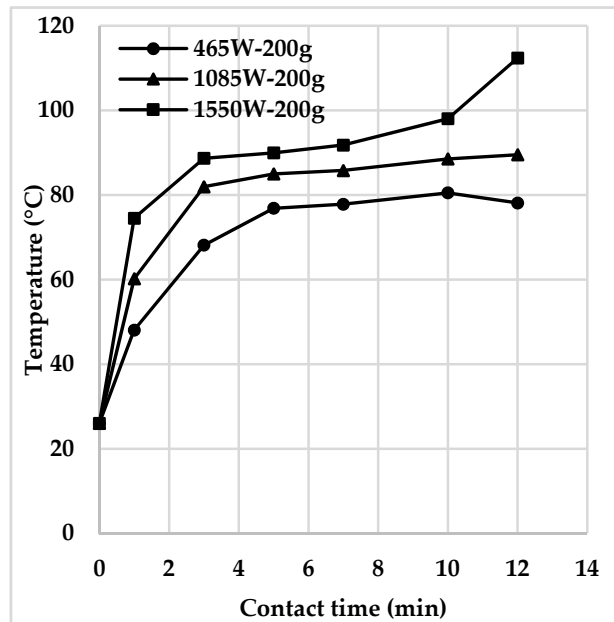

(b)

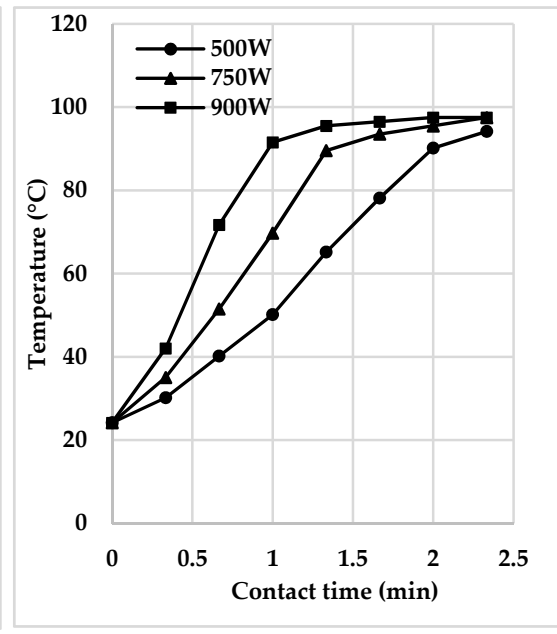

(c)

Figure 2. Dependence of temperature on the time of MW-heating of: (a) faecal sludge in Kenya, $100 \mathrm{~g}$ sample [27]; (b) faecal sludge in Kenya, $200 \mathrm{~g}$ sample [27]; and (c) active sludge in China Reprinted with permission from ref. [25].

As a rule, the efficiency of the MW system tends to rise with the increase of power and time of microwave irradiation [22]. It is due to the release of extra heat, contributing to the rapid movement of water molecules. In addition, increased time and power of irradiation amplify the decomposition of various contaminants in the water environment [9].

In some cases, the efficiency of the MW system is reduced at very high temperatures by evaporating water and increased viscosity of the substance by overheating. Thus, it is necessary to determine the optimal power and reaction temperature for decomposing a particular target pollutant $[9,14,17-21]$.

It should be noted that the technological and economic efficiency of MW heating for the water environment is currently actively explored by contrasting it to other methods of heating and processing $[14,23,24]$. The Department of Water Supply and Sanitation (Industrial University of Tyumen, Russia) laboratory has carried out several experiments related to the MW-heating of wastewater sludge [14,24]. Firstly, a comparison is made between microwave and electric heating. The distinctive feature of microwave heating is its thermal effect, which is volumetric and does not involve thermal diffusion from the surface into the material, as conventional heating does, which explains its high thermoset reaction rates. According to observations, ultrahigh-frequency irradiation of liquid sewage sludge has a rapid thermal effect: samples of sludge with a 50-300 mL volume started to boil within one to two minutes (Figure 3) [14]. 


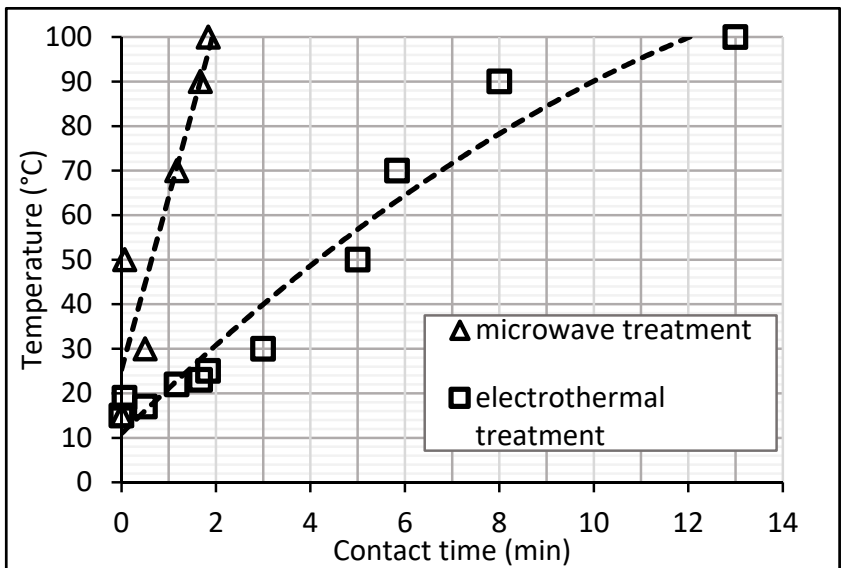

(a)

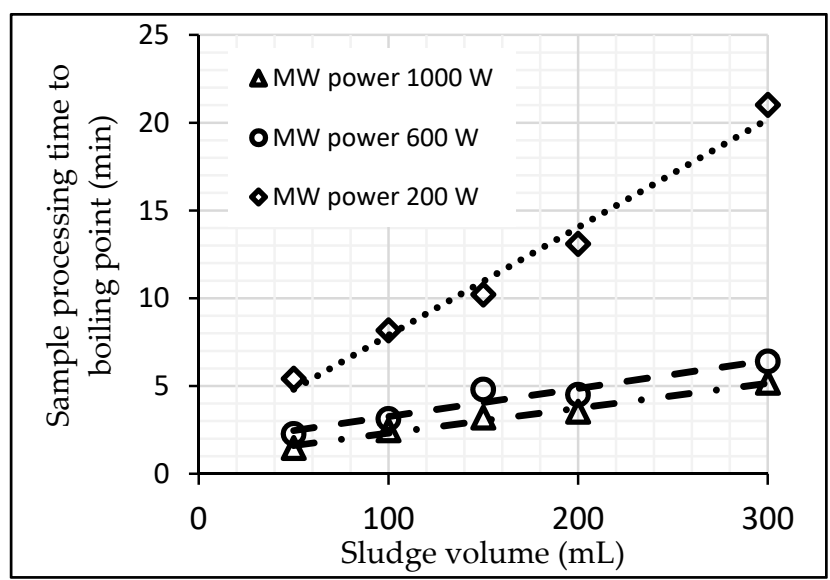

(b)

Figure 3. (a) Comparison of two methods of WWS-heating. (b) Boiling time dependence of the WWS on the sample volume at a constant power MW.

Figure 3a compares the heating curves of sewage sludge (mixture of the raw sludge and activated sludge) in two different ways, with the rate of heating the sludge to a given temperature using microwaves being four to six times faster than the usual heating on an electric stove. In addition, in the process of microwave irradiation, an improvement in the sedimentation and compaction of WWS was obtained by $13-15 \%$ compared to traditional convective heating to the same temperature [14].

Secondly, the maximum time for MW treatment of WWS samples to reach boiling point [24] was determined experimentally. Figure $3 b$ illustrates dependency $t=f(V)$ at constant power MW based on the experience data. Obviously, the higher the microwave processing power, the faster the sludge samples reach the boiling point. At MW $200 \mathrm{~W}$, the heating rate of sewage sludge is 3.7-4.0 times lower than at MW $1000 \mathrm{~W}$ and 3-2.8 times lower than at MW $600 \mathrm{~W}$. Heating sludge with a power of $1000 \mathrm{~W}$ is 1.2 times more effective than heating with $600 \mathrm{~W}$. Rapid and voluminous MW-heating of wastewater and sediments entails other positive effects discussed below.

\subsection{Properties Change}

\subsubsection{Wastewater}

Almost all researchers usually note changes in individual physical and chemical properties of wastewater and sludge under MW influence. The scope of the study includes such properties of water as temperature, viscosity, $\mathrm{pH}$, electrical conductivity, and surface tension. There is a change in some quality indicators of water. However, some results are not widely confirmed, for example, the change in the structure of water under the influence of electromagnetic radiation.

In the studies presented, water samples from 100 to $300 \mathrm{~mL}$ were subjected to MW irradiation in MW furnaces of various powers from $30 \mathrm{~W}$ to $900 \mathrm{~W}$ and frequency $\mathrm{f}=2.45 \mathrm{GHz}$ during periods from thirty seconds to ten minutes. In some cases, experiments were carried out on pure water [28-32] and required testing on wastewater. Table 3 provides examples of changes in water or wastewater physicochemical properties under the influence of MW, as measured in batch laboratory studies. 
Table 3. Changes in the physical and chemical properties of water/wastewater under the influence of MW.

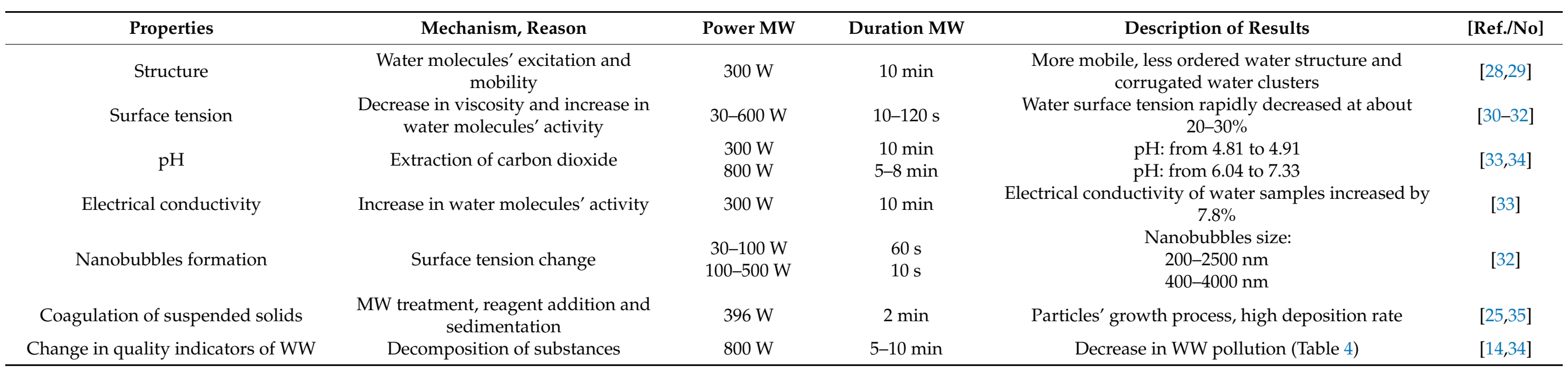


According to earlier studies [24,25], published back in the 1980s and 1990s, the structure of water after treatment with electromagnetic radiation changes: it becomes more mobile, less ordered, and expanded water clusters can be transformed into a corrugated structure. However, there has been no confirmation of these conclusions or further study on the wastewater samples in recent publications found.

According to the observations, during the microwave irradiation process, the water surface tension rapidly decreased along with the temperature growth. Once the microwave irradiation was turned off, the temperature quickly recovered, as expected. However, the surface tension remained significantly below the initial value for an extended period. The minimal surface tension depended on the MW power. Moreover, the repeated procedure can additionally reduce the surface tension. For example, a water sample irradiated for $120 \mathrm{~s}$ at a power of $600 \mathrm{~W}$ had the surface tension decreased from 75 to 55 , and this effect persisted for one hour. There is a change to the alkaline side due to the release of carbon dioxide. Surface tension experiments were carried out in the laboratory on specifically constructed equipment [30,31].

The $\mathrm{pH}$ change is proportional to the MW treatment's power and time: the greater the power and duration, the more significant the $\mathrm{pH}$ change. Due to a rise in the water molecules' mobility, the electrical conductivity of water samples increased by $7.8 \%$, from 0.9 to $0.97(\mathrm{uS} / \mathrm{cm})$. An improvement in the solubility of substances in water was also observed [30]. The nanobubbles formation was observed during the MW heating of the samples. It can be explained by a change in the surface tension [32].

The coagulation of suspended substances in wastewater under the influence of microwave irradiation is intensified during short-term treatment (one to two minutes). In order to analyse the wastewater of a metallurgical enterprise, after the treatment of blast furnace gases, polyaluminum chloride and phosphoric acid solutions were applied to water samples as catalysts for the coagulation of suspended substances. As a result, the concentration of suspended substances with preliminary microwave irradiation of the samples was 10-15\% lower. In addition, it occurs that pretreatment with MW intensifies the reduction of turbidity and water hardness in the process of reagent coagulation [31].

Some authors also noted changes in wastewater quality indicators. Experiments in [14], for example, showed that the quality of sewage under the influence of MW electromagnetic irradiation improved. Table 4 illustrates the shift in wastewater criteria following microwave treatment. Results have been derived from batch experiments.

Table 4. Water indexes change after MW treatment [14].

\begin{tabular}{|c|c|c|c|}
\hline Wastewater Indexes & $\begin{array}{l}\text { Inlet } \\
\text { Concentration } \\
\text { before MW, } \\
\text { mg/L }\end{array}$ & $\begin{array}{l}\text { Outlet } \\
\text { Concentration } \\
\text { after MW, mg/L }\end{array}$ & Description of Results \\
\hline Suspended matters & 940 & 850 & $\begin{array}{c}\text { The concentration decreases from } 940 \text { to } 450 \mathrm{mg} / \mathrm{L} \text { (after first } \\
\text { stage) and then increases to } 850 \mathrm{mg} / \mathrm{L} \text { (after second stage). } \\
\text { Efficient is } 9.5 \%\end{array}$ \\
\hline $\begin{array}{c}\text { Chemical oxygen } \\
\text { demand (COD) }\end{array}$ & 1240 & 490 & Efficient is $60.5 \%$ \\
\hline $\begin{array}{l}\text { Biological oxygen } \\
\text { demand (BOD) }\end{array}$ & 430 & 250 & $\begin{array}{c}\text { The concentration decreases from } 430 \text { to } 250 \mathrm{mg} / \mathrm{L} \text { (after first } \\
\text { stage) and then increases to } 280 \mathrm{mg} / \mathrm{L} \text { (after second stage). } \\
\text { Efficient is } 35 \%\end{array}$ \\
\hline Ammonium-ion & 200 & 150 & Efficient is $25 \%$ \\
\hline Nitrate-ion & 0 & 3.8 & $\begin{array}{l}\text { The concentration increases by reason of the destruction of } \\
\text { organic matters and transformation ammonium nitrogen into } \\
\text { nitrate-ion }\end{array}$ \\
\hline Phosphate-ion & 29 & 19 & Efficient is $34.5 \%$ \\
\hline Sulfates & 14 & 2 & Efficient is $85.7 \%$ \\
\hline Chlorides & 4.8 & 2.8 & Efficient is $41.7 \%$ \\
\hline $\mathrm{pH}$ & 6.04 & 7.33 & The environment became more neutral \\
\hline
\end{tabular}




\subsubsection{Wastewater Sludge}

Microwave WWS treatment is mainly concerned with liquid municipal waste. There are quite a lot of studies on changing the properties of activated sludge; to a lesser extent, there are studies on a mixture of raw sediments and activated sludge, as well as studies on raw sediment separately. Few publications on the study of the properties of dehydrated sediments are available. Temperature and viscosity, moisture yield, compaction intensity, and mineralisation are all features that usually put into the analysis. It is worth mentioning that certain properties of WWS (compaction/deposition rate, resistivity, capillary suction time, and others) change for the better until the turning point (characterised by the power and duration of irradiation), after which they irreversibly deteriorate due to the high rate of water evaporation.

Many observers note a high level of disinfection of all WWS types (Section 3.3). Less attention is paid to the release of metals into the supernatant water, increasing stability, reducing rotting, and changing the structure of wastewater sediments. Table 5 shows variations in the physical and chemical properties of WWS under the influence of MW (frequency $\mathrm{f}=2.45 \mathrm{GHz}$ ); the results have been derived from batch experiments.

Table 5. Changes in the physical and chemical properties of WWS under the influence of MW.

\begin{tabular}{|c|c|c|c|c|c|}
\hline WWS Properties & $\begin{array}{c}\text { WWS Form, } \\
\text { Processing Method }\end{array}$ & MW Power & Duration MW & Description of Results & [Ref./No] \\
\hline Structure change & $\begin{array}{l}\text { Activated sludge; a } \\
\text { mixture of activated } \\
\text { sludge and raw } \\
\text { sediment }\end{array}$ & $450-900 \mathrm{~W}$ & $1-10 \mathrm{~min}$ & $\begin{array}{l}\text { Sediment's structure } \\
\text { changes: the flakes } \\
\text { firstly expand than } \\
\text { collapse }\end{array}$ & {$[25,34,36]$} \\
\hline Temperature & $\begin{array}{l}\text { Activated sludge; a } \\
\text { mixture of activated } \\
\text { sludge and raw } \\
\text { sediment }\end{array}$ & $300-900 \mathrm{~W}$ & $1-10 \mathrm{~min}$ & $\begin{array}{l}\text { Rise in temperature and } \\
\text { rapid boiling at } 100{ }^{\circ} \mathrm{C}\end{array}$ & {$[25,34,36]$} \\
\hline \multirow[t]{2}{*}{$\begin{array}{l}\text { Resistivity } \\
\text { (fluidity) }\end{array}$} & Mixed sediments & $800 \mathrm{~W}$ & $3-4 \mathrm{~min}$ & $\begin{array}{l}\text { Decrease in viscosity } \\
\text { and resistivity by } 5 \text { times }\end{array}$ & {$[25,34,36,37]$} \\
\hline & $\begin{array}{l}\text { Raw sediment, mixed } \\
\text { sediments }\end{array}$ & $550 \mathrm{~W}$ & $6 \mathrm{~min}$ & $\begin{array}{l}\text { A decrease of } 73-84 \% \\
\text { from the original value } \\
\text { for raw sediment and a } \\
\text { mixture of sediments }\end{array}$ & [38] \\
\hline Humidity & $\begin{array}{l}\text { Activated sludge, raw } \\
\text { sediment, and mixed } \\
\text { sediments }\end{array}$ & $450-800 \mathrm{~W}$ & $1-8 \mathrm{~min}$ & $\begin{array}{l}\text { Humidity decreases by } \\
\qquad 2-3 \%\end{array}$ & {$[34,36]$} \\
\hline \multirow[t]{2}{*}{ Moisture output } & $\begin{array}{l}\text { Mixture of sediments; } \\
\text { activated sludge with } \\
\text { the addition of an acid } \\
\text { solution and heating } \\
\text { to } 100^{\circ} \mathrm{C}\end{array}$ & $600-900 \mathrm{~W}$ & $1-5 \min$ & $\begin{array}{l}\text { The time of capillary } \\
\text { absorption of the } \\
\text { sediment mixture is } \\
\text { reduced by } 1.2-1.3 \text { times; } \\
\text { when the pH changes to } \\
2.0-2.4 \text { of the activated } \\
\text { sludge, a reduction of } 4 \\
\text { times is achieved }\end{array}$ & {$[25,34,36,37,39]$} \\
\hline & $\begin{array}{c}\text { Raw sediment, mixed } \\
\text { sediment, fermented } \\
\text { sediment }\end{array}$ & $500-600 \mathrm{~W}$ & $1-1.5 \mathrm{~min}$ & $\begin{array}{l}\text { The minimum capillary } \\
\text { suction time is achieved } \\
\text { only in the first } 1-2 \text { min } \\
\text { of treatment to a } \\
\text { temperature of } 60-80{ }^{\circ} \mathrm{C} \text {, } \\
\text { then it begins to increase }\end{array}$ & {$[38,40,41]$} \\
\hline
\end{tabular}


Table 5. Cont.

\begin{tabular}{|c|c|c|c|c|c|}
\hline WWS Properties & $\begin{array}{l}\text { WWS Form, Processing } \\
\text { Method }\end{array}$ & MW Power & $\begin{array}{l}\text { Duration } \\
\text { MW }\end{array}$ & Description of Results & [Ref./No] \\
\hline $\begin{array}{c}\text { Compaction } \\
\text { (sedimentation) }\end{array}$ & Activated sludge & $\begin{array}{l}900 \mathrm{~W} \\
750 \mathrm{~W}\end{array}$ & $\begin{array}{l}60 \mathrm{~s} \\
80 \mathrm{~s}\end{array}$ & $\begin{array}{l}\text { The settling velocity } \\
\text { increases (the settling } \\
\text { time is } 24 \mathrm{~h} \text { ) }\end{array}$ & {$[25,34,36,37]$} \\
\hline Mineralisation & $\begin{array}{c}\text { A mixture of raw } \\
\text { sediment and activated } \\
\text { sludge; activated sludge }\end{array}$ & $800 \mathrm{~W}$ & $8 \mathrm{~min}$ & $\begin{array}{l}\text { Increase in the ash } \\
\text { content of the } \\
\text { wastewater sludge } \\
\text { mixture by } 6.1 \% ; \\
\text { intensification of } \\
\text { solubilisation of organic } \\
\text { matter }\end{array}$ & [31-34] \\
\hline $\begin{array}{l}\text { Dry matter content } \\
\text { in the cake }\end{array}$ & $\begin{array}{c}\text { Dehydrated municipal } \\
\text { sediment }\end{array}$ & $550 \mathrm{~W}$ & $0.5-4 \mathrm{~min}$ & $\begin{array}{l}\text { In the raw sediment, the } \\
\text { dry matter content } \\
\text { increases by } 8 \% \text {; in the } \\
\text { mixture and in the } \\
\text { fermented-by } 2 \% \text {. }\end{array}$ & [38] \\
\hline Cake ${ }^{*}$ humidity & $\begin{array}{c}\text { Dehydrated municipal } \\
\text { sediment }\end{array}$ & $400 \mathrm{~W}$ & $2 \min$ & May achieve $28 \%$ & [38] \\
\hline Decontamination & $\begin{array}{l}\text { Raw sediment, mixed } \\
\text { sediments }\end{array}$ & 800-900 W & $1-8 \mathrm{~min}$ & $\begin{array}{l}\text { Reducing the content of } \\
\text { pathogenic } \\
\text { microorganisms by } 99 \%\end{array}$ & $\begin{array}{c}{[14,26,27,31,33,34,} \\
37,42,52]\end{array}$ \\
\hline
\end{tabular}

${ }^{*}$ cake-dehydrated WWS.

Some publications $[25,34,36]$ provide evidence of changes in the structure of wastewater sediments under the influence of MW irradiation. Microwave processing of activated sludge has a tipping point: up to a certain length at a constant strength, the flakes firstly expand (for example, at $900 \mathrm{~W}$ for the first one to two minutes), then the more extended process (over two minutes) destroys them [25]. At the same time, the structure becomes more homogeneous and dispersed [36].

A change in the spatial configuration of samples of a sediment mixture after MW heating to a temperature of $75^{\circ} \mathrm{C}[34,36]$ was observed during a microbiological analysis using an electron microscope Micromed 2 (3-20). Figure 4 provides a view of a mixture of raw sediment and activated sludge in a ratio of 1:2, increased by 40 times.

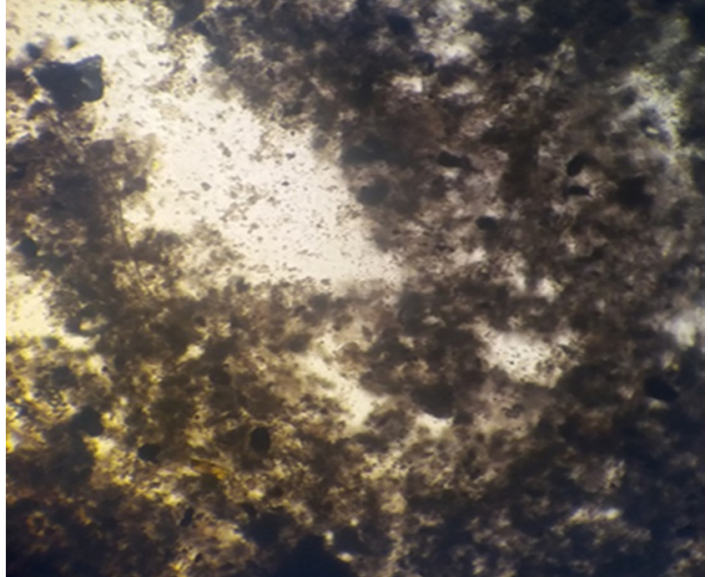

(a)

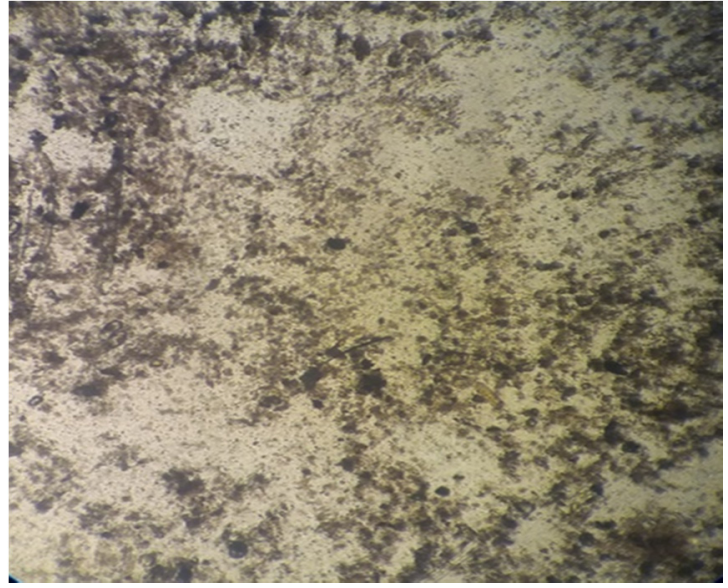

(b)

Figure 4. Structure of the initial mixture of primary sediments and activated sludge (a) and after MW treatment (b). 
The initial structure of the sediment flakes (Figure 4a) is uneven, coarse-dispersed, with separate large conglomerates, saturated with protozoan bacteria. The species composition of the sample of the initial sediment mixture is as follows: filamentous bacteria, small benthic shell amoebas, free-floating infusoria, aspidiscs, and rotifers. There are no visible shell deformations. When analyzing images of samples of a mixture of primary raw sediment and activated sludge under a microscope before and after microwave treatment, when the heating temperature reaches $75^{\circ} \mathrm{C}$ (Figure $4 \mathrm{~b}$ ), significant changes in the spatial structure of the samples under study are visually determined. For example, the structure of the treated sediment becomes finely dispersed and more uniform, and individual large silt conglomerates disintegrate. In addition, when analysing the external state of bacteria, there are visible deformations of their shells: arcella have a distorted shape, and the shells of rotifers are crumpled [34]. During MW treatment of any sewage sludge, there is a rapid increase in the temperature of the samples (in one to five minutes, samples with a volume of $100-300 \mathrm{~mL}$ at a power of 900 to $450 \mathrm{~W}$ reach $100^{\circ} \mathrm{C}$ ) as a result of the thermal effect of microwaves (see Section 3.1).

In the process of heating the sediments, there is a decrease in viscosity and resistivity of filtration. This decrease is observed when the evaporation of moisture is not so great until the critical moment. After microwave heating, the effect of reduced resistivity retains. Analysis of a series of experiments showed that MW treatment of sewage sludge during four minutes at a power of $800 \mathrm{~W}$ significantly reduces the specific resistance of filtration: the initial sludge average value of resistance is $37.15 \times 10^{-10} \mathrm{~cm} / \mathrm{g}$ with an allow for an error of no more than $10 \%$, after microwave treatment it is $6.93 \times 10^{-10} \mathrm{~cm} / \mathrm{g}[34,36]$. Under the further remained heating, the viscosity and resistivity can rise due to excessive evaporation after a turning point at a certain power and length of MW-treatment, which are calculated separately for each form of WWS [25]. It was verified in publication [37], where for wet sludge and a mixture of sludge were obtained the best resistivity results of a $73-84 \%$ reduction from the initial value after $180 \mathrm{~s}$ per minute at a processing power of $550 \mathrm{~W}$. In the MW-treated fermented sediment, the maximal effect of reducing the resistivity reached only $18 \%$ [38].

The moisture-yielding properties of WWS play a vital role in the efficiency and duration of dewatering and volume reduction. The capillary suction period is the essential feature of moisture loss. In the experiments, when wastewater sludge was microwave irradiated for five minutes at a power of $0.8 \mathrm{~kW}$, capillary suction time was reduced by approximately 1.2 times relative to untreated WWS [39-41]. This is explained by the fact that part of the bound water passes into the free state and evaporates during the MW treatment. However, due to a prolonged process over eight minutes, the capillary suction time increases by 2.4 times on average since significant moisture evaporation occurs and the sediment becomes viscous [34].

The moisture release of sludge can be intensified by reducing the $\mathrm{pH}$ to 2.5 at $\mathrm{T}=100^{\circ} \mathrm{C}$ : the capillary suction time (CST) is reduced from $37.7 \mathrm{~s}$ to $9.2 \mathrm{~s}$ (approximately four times), and the content of bound water is reduced from $1.96 \pm 0.19 \mathrm{~g} / \mathrm{g}$ to $0.88 \pm 0.24 \mathrm{~g} / \mathrm{g}$ of dry residue [37].

Domestic wastewater sludge has a humidity of $93-99.8 \%$ and is at the initial stage almost a highly concentrated water suspension, saturated with organic substances and bacterial contaminants. All WWS treatment methods aim to minimise its volume and achieve the required conditioned state for further disposal. The decrease in volume achieved by reducing the moisture content of the sediment to $50-70 \%$ is possible when compacting, dewatering in natural conditions on open silt sites, and mechanical dewatering on special equipment. Compacting usually takes from five to twenty hours, with the moisture content of the sludge reduced by $10-15 \%$. Better results of humidity decrease to $50-70 \%$ can be achieved by dewatering in natural conditions, though this process takes from one to six months. The mechanical method's cycle duration is up to only one hour. The pace of the processes mentioned above depend on the sediment's ability to give off chemically un- 
bound moisture. The moisture yield, in turn, directly relates to the quality of composition of the sediment and the transition of water from colloids to the free state [37].

The optimal time for MW treatment of activated sludge is $60 \mathrm{~s}$ at $900 \mathrm{~W}$ power and $80 \mathrm{~s}$ at $750 \mathrm{~W}$ [25]. At this point, the peak deposition rate is reached. With the increase of microwave processing time, the deposition/compaction rate will again decrease.

There is an experience of long-term MW processing of WWS from 30 to $240 \mathrm{~min}$ at a power of $3.4 \mathrm{~kW}$. In this case, it is possible to reduce the volume of sediment by $60 \%$ due to intensive evaporation [41].

In all forms of WWS, there is a decrease in organic matter content. Several mechanisms mediate this response:

(1) Solubilisation occurs at certain microwave irradiation capacities (up to $900 \mathrm{~W}$ ) and short phase durations (up to $140 \mathrm{~s}$ ). Organic matter is released into the soluble phase during this process [25]. At the same time, COD levels in the sediment rise slightly as a result of microwave irradiation's ability to dissolve silt floccules. As a result, organic substances are hydrolysed into simpler forms, which are easily oxidised by microorganisms [37].

(2) When the sediments are exposed to MW radiation, the oxygen molecules in the sediments become stimulated or excited and they participate directly in the oxidative reactions of organic matter. Various oxidising agents can be added to speed up this process (see Section 3.4).

The ash content of WWS increases as a result of the mineralisation process (by $6-7 \%$ for a mixture of wastewater sludge under $8 \mathrm{~min}$ of MW irradiation time and power of $800 \mathrm{~W}$ ) and the stability of WWS, faecal odour, and rotting of wastewater sludge during long-term storage decreases significantly [34].

\subsection{Decontamination (Disinfection)}

In the last century, the biophysical impact of the MW field on the viability and other properties of bacteria was discovered $[43,44]$. The sterilising efficiency of the MW field produced by the GZ-10A generator when irradiated for $10 \mathrm{~min}$, for example, was used to assess the biological effect of microwaves on microorganisms [45]. The bacteria's viability was determined by the number of colonies developed within two days on the breeding ground. As a result, researchers discovered a bactericidal effect of pulsed and continuous microwaves on Escherichia coli and staphylococcus cultures.

Experiments on the influence of centimetre waves on the growth of Escherichia coli $\mathrm{M}-17$ in a continuous mode (frequency $10.6 \mathrm{GHz}, \mathrm{PPM}=0.1-5.5 \mathrm{MW} / \mathrm{cm}^{2}$ ) are presented in the paper [46]. According to the material results, microwave radiation has a harmful effect on escherichia coli $(n=10)$ at a power of $130 \mathrm{~W}$ for five minutes [47]. Water heating and disinfection systems were invented and patented in the 1970s and 1980s $[48,49]$.

The modern use of MW for wastewater disinfection is based on earlier studies [50,51]. Less often it is mentioned that sewage sludge is also disinfected during microwave irradiation $[14,26,27,31,33,34,37,42,52]$. Water disinfection usually occurs at a power of MW from $300 \mathrm{~W}$ and higher (frequency $2.45 \mathrm{GHz}$ ) when heated from 45 to $100{ }^{\circ} \mathrm{C}$. Therefore, the processing time depends on the sample volume and the MW heating power. This knowledge is very relevant concerning the further disposal of such liquid municipal waste. For example, faecal sludge formed in public toilets was treated using a laboratory microwave installation (MW) [26,27].

Total bacterial inactivation was achieved in 30-240 min after sewage sludge treatment in a special MW reactor [42]. According to findings in [52], high-level disinfection for enterococci and salmonella is possible to achieve in $9.5 \mathrm{~min}$ at MW energy consumption of $580 \mathrm{~W} \cdot \mathrm{s} / \mathrm{g}$ and temperature $72{ }^{\circ} \mathrm{C}$. In some studies [53,54], microwave irradiation proved to effectively reduce the bacterial content of sewage sludge prior to anaerobic digestion. In addition, a high degree of removal of faecal coliforms in the sediment is recorded in [55] (the content of 2.66 logs or less).

Similarly, researchers [56] confirmed that a single pretreatment with microwaves resulted in a $50 \%$ reduction of bacteria C.Perfringens. Furthermore, according to the 
article [14], the microwave treatment of a mixture of sewage sludge can achieve $99 \%$ decontamination from all pathogenic bacteria subject to control.

The MW technology can be further investigated for potential expansion as a rapid treatment alternative for faecal effluents and sediments in emergencies [26,27], such as a pandemic.

\subsection{Decomposition of Organic Substances}

Organic pollution of natural and wastewater is a source of concern for scientists and environmentalists worldwide, as these contaminants have a detrimental impact on the natural environment, human life, and health. Approximately 3000 different organic contaminants have been identified [57,58] and classified into three groups: (1) organic substances of natural origin, (2) synthetic organic pollutants, and (3) chemicals reformed in water as a result of its purification. Many organic pollutants of the second and third groups are toxins and carcinogens [59]. Therefore, the international community is looking for creative, highly efficient advanced oxidative water treatment technologies that involve various pollutant exposure processes to address this problem.

In order to increase the performance of WW treatment from different contaminants and minimise reaction time, microwave exposure should be combined with oxidising agents $\mathrm{OX}(\mathrm{MW}+\mathrm{OX})$, adsorbents activated carbon $\mathrm{AC}(\mathrm{MW}+\mathrm{OX}+\mathrm{AC})$, catalysts carbon $\mathrm{C}(\mathrm{MW}+\mathrm{OX}+\mathrm{C})$, and advanced oxidation processes with the addition of UV irradiation such as photo-Fenton ( $\mathrm{MW}+\mathrm{OX}+\mathrm{C}+\mathrm{UV})$, direct photolysis using an electrodeless discharge lamp EDL (MW+OX+EDL), and photocatalysis using $\mathrm{TiO}_{2}$ photocatalyst ( $\mathrm{MW}+$ $\left.\mathrm{OX}+\mathrm{UV}+\mathrm{TiO}_{2}\right)$ [60-72].

The review data were summarised reasonably well in the papers $[9,73]$. Other studies of the efficacy of MW oxidation of organic compounds under various treatment conditions are seen in Table 6 [22,61-72].

The addition of microwaves to oxidising agents accelerates the oxidation of organic compounds due to dipolar polarisation. For each pollutant, the form of oxidising agents, necessary doses, and reaction conditions (including temperature, strength, and treatment period MW) are calculated separately $[64,66]$. Microwave capacity ranges from $300 \mathrm{~W}$ to $900 \mathrm{~W}$, temperature ranges from $20^{\circ} \mathrm{C}$ to $130^{\circ} \mathrm{C}$, and processing time ranges from three minutes to one hour, depending on sample volume. Thus, the pollutant characteristics and their resistance to temperature and chemical factors affect the variance of parameter values.

Various catalysts, such as ferromagnetic metal, transition metal oxides, various types of activated carbons, and others, are applied to the water to increase the MW oxidation of organic compounds. The catalysts can be added to the water in two different ways: a suspension accompanied by sedimentation or a fixed filter plate. At the same time, the removal efficiency for a wide range of organic pollutants is about $85-100 \%$ [9].

A promising technology for the degradation of organic pollutants, even from the stage of mineralisation, is considered to be catalytic oxidation by moist air (CWAO) under conditions of high temperature $\left(180-315^{\circ} \mathrm{C}\right)$ and pressure $(2-25 \mathrm{MPa})$, with the addition of catalysts [9]. The photo-Fenton process is based on the use of the Fenton reagent, that is, a mixture of $\mathrm{Fe}^{2+}$ salt (catalyst) and hydrogen peroxide (oxidiser) in combination with ultraviolet irradiation (UV). The study [9] provides research on the decomposition and mineralisation of different organic pollutants and reveals that compared to Fenton and photo-Fenton processes without MW, the decomposition rate of various pollutants increases by at least 50 times. 
Table 6. The efficiency of MW oxidation of organic substances in WW.

\begin{tabular}{|c|c|c|c|c|c|c|c|}
\hline Type of an Organic Substance & Sample Volume & Concentration & $\begin{array}{l}\text { Oxidizing Agent, } \\
\text { Catalyst, pH }\end{array}$ & MW Power & $\begin{array}{l}\text { MW Duration, } \\
\text { Temperature }\end{array}$ & Effect & [Ref./No] \\
\hline \multicolumn{8}{|c|}{ Sample was only MW-treated } \\
\hline Ammonia (laboratory installation) & $100 \mathrm{~mL}$ & $0.5-12 \mathrm{~g} / \mathrm{L}$ & $\begin{array}{l}\text { Air } 1 \mathrm{~L} / \mathrm{min} \\
\mathrm{pH}=11\end{array}$ & $750 \mathrm{~W}$ & $\begin{array}{l}3 \min \\
80^{\circ} \mathrm{C}\end{array}$ & $\mathrm{D} * 98.4-96.1 \%$ & [63] \\
\hline Ammonia (pilot plant) & $28,000 \mathrm{~mL}$ & $2.4-11 \mathrm{~g} / \mathrm{L}$ & $\begin{array}{l}\text { Air } 30 \mathrm{~L} / \mathrm{min} \\
\mathrm{pH}=11.6-12\end{array}$ & $4.8 \mathrm{~kW}$ & $\begin{array}{c}60 \mathrm{~min} \\
80-100^{\circ} \mathrm{C}\end{array}$ & $\mathrm{D} * 80 \%$ & [63] \\
\hline \multicolumn{8}{|c|}{ With an addition of the oxidizer: MW + OX } \\
\hline Naphthalene Disulfonic Acid & $10 \mathrm{~mL}$ & $1.0 \mathrm{mmol} / \mathrm{L}$ & $\mathrm{H}_{2} \mathrm{O}_{2}$ & $300 \mathrm{~W}$ & $\begin{array}{l}20 \mathrm{~min} \\
30 \mathrm{~min} \\
80^{\circ} \mathrm{C}\end{array}$ & $D * 90 \% M * 50 \%$ & {$[64]$} \\
\hline Dimethoate (phosphoric compound) & No Data & $0.1 \mathrm{mmol} / \mathrm{L}$ & $\begin{array}{c}\mathrm{K}_{2} \mathrm{~S}_{2} \mathrm{O}_{8} \\
\mathrm{pH}=6.8\end{array}$ & $750 \mathrm{~W}$ & $\begin{array}{c}4 \mathrm{~min} \\
100^{\circ} \mathrm{C}\end{array}$ & $D * 100 \%$ & [22] \\
\hline Perflurooctanic acid & $50 \mathrm{~mL}$ & $0.25 \mathrm{mmol} / \mathrm{L}$ & $\mathrm{Na}_{2} \mathrm{~S}_{2} \mathrm{O}_{8}$ & $800 \mathrm{~W}$ & $\begin{array}{c}240 \mathrm{~min} \\
60-130^{\circ} \mathrm{C}\end{array}$ & $\begin{array}{l}D * 99.3 \% \\
M * 74.3 \%\end{array}$ & [66] \\
\hline Polyacrylamide (PAA) & No Data & $\begin{array}{l}\text { The photo-F } \\
150 \mathrm{mg} / \mathrm{L}\end{array}$ & $\begin{array}{c}\text { process: } \mathrm{MW}+\mathrm{OX} \\
\mathrm{H}_{2} \mathrm{O}_{2} / \mathrm{AC} \\
\mathrm{pH}=3\end{array}$ & $\begin{array}{l}\text { UV } \\
70 \mathrm{~W} \\
490 \mathrm{~W}\end{array}$ & $6 \min$ & $\begin{array}{l}D * 20 \% \\
D * 80 \%\end{array}$ & [61] \\
\hline Pesticides (dimethoate, triazophos, malathion) & $1000 \mathrm{~mL}$ & $6.11-31.65 \mathrm{mg} / \mathrm{L}$ & $\begin{array}{c}\mathrm{H}_{2} \mathrm{O}_{2} \\
\mathrm{Fe}^{2+} ; \mathrm{pH}=5\end{array}$ & $80 \mathrm{~W}$ & $\begin{array}{l}120 \min \\
25^{\circ} \mathrm{C}\end{array}$ & $M * * 72.1 \%$ & [62] \\
\hline \multicolumn{8}{|c|}{ Direct photolysis: MW + OX + EDL } \\
\hline Phenol & $50 \mathrm{~mL}$ & $200 \mathrm{mg} / \mathrm{L}$ & $\mathrm{H}_{2} \mathrm{O}_{2}$ & $1000 \mathrm{~W}$ & $\begin{array}{c}9 \mathrm{~min} \\
30 \mathrm{~min} \\
50^{\circ} \mathrm{C}\end{array}$ & $\begin{array}{c}D * 90 \% \\
M * 95 \%\end{array}$ & [67] \\
\hline Atrazine & $50 \mathrm{~mL}$ & $50 \mathrm{mg} / \mathrm{L}$ & $\mathrm{pH}=6.3$ & $900 \mathrm{~W}$ & $\begin{array}{l}30 \mathrm{~min} \\
30^{\circ} \mathrm{C}\end{array}$ & $D * 100 \%$ & {$[68]$} \\
\hline \multicolumn{8}{|c|}{ Photocatalysis: $\mathrm{MW}+\mathrm{OX}+\mathrm{UV}+\mathrm{TiO}_{2}$} \\
\hline Methylene Blue (aromatic compound) & $50 \mathrm{~mL}$ & $100 \mathrm{mg} / \mathrm{L}$ & $\begin{array}{c}\mathrm{TiO}_{2} \text { load } \\
\mathrm{pH}=7\end{array}$ & $900 \mathrm{~W}$ & $\begin{array}{l}15 \mathrm{~min} \\
100^{\circ} \mathrm{C}\end{array}$ & $\begin{array}{c}D * 96 \% \\
M * 50 \%\end{array}$ & [69] \\
\hline 2,4-D chlorophenoxyacetic herbicide & $10 \mathrm{~mL}$ & $0.04 \mathrm{mmol} / \mathrm{L}$ & $\begin{array}{l}\mathrm{TiO}_{2} \text { load } \\
\mathrm{pH}=4.9\end{array}$ & $700 \mathrm{~W}$ & $20 \mathrm{~min}$ & $\mathrm{D} * 100 \%$ & [70] \\
\hline Bisphenol A (Endocrine disruptor) & $30 \mathrm{~mL}$ & $0.1 \mathrm{mM}$ & $\begin{array}{l}\mathrm{TiO}_{2} \text { load } \\
\mathrm{pH}=6.7\end{array}$ & $1500 \mathrm{~W}$ & $90 \mathrm{~min}$ & $M * * 100 \%$ & [71] \\
\hline Phenol & $50 \mathrm{~mL}$ & $10 \mathrm{mg} / \mathrm{L}$ & $\mathrm{TiO}_{2} / \mathrm{AC}$ & $900 \mathrm{~W}$ & $30 \mathrm{~min}$ & $\mathrm{D} * 87 \%$ & [72] \\
\hline Atrazine & $50 \mathrm{~mL}$ & $20 \mathrm{mg} / \mathrm{L}$ & $\begin{array}{c}\mathrm{TiO}_{2} \text { nanotubes } \\
\text { pH }=8.1\end{array}$ & $900 \mathrm{~W}$ & $\begin{array}{l}5 \mathrm{~min} \\
20 \mathrm{~min}\end{array}$ & $\begin{array}{c}D * 100 \% \\
M * * 98.5 \%\end{array}$ & [72] \\
\hline
\end{tabular}

$\mathrm{D}^{*}$ - destruction efficiency; $\mathrm{M} *$ - mineralisation efficiency. 
Electrodeless discharge lamp (EDL) use eliminates the issue of electrode destruction in a conventional mercury-based UV lamp. EDL consists of a glass tube-a plasma chamber filled under reduced pressure with argon and excitable matter $\left(\mathrm{Hg}, \mathrm{HgI}_{2}, \mathrm{Cd}, \mathrm{I} 2, \mathrm{KI}, \mathrm{P}, \mathrm{Se}\right.$, and S) and generating UV radiation under the action of MW (direct photolysis-MWDP). Together with microwaves and oxidising agents, MWDP is considered the most effective by many authors $[9,67,68,74,75]$.

Microwave photocatalysis emerged to speed up and deepen organic carbon oxidation and mineralisation reactions, preventing secondary corrosion and iron-containing sediment production. The $\mathrm{TiO}_{2}$ semiconductor photocatalyst is commonly used in this method in grains, nanoporous films, and nanotubes. In addition, the $\mathrm{TiO}_{2}$ composite catalyst supported on activated carbon $\mathrm{TiO}_{2} / \mathrm{AC}$ shows good results [9].

The authors $[9,13,65,76]$ consider the most critical factors influencing the efficiency of decomposition and mineralisation of organic pollutants based on comprehensive experimental experience with microwaves for the removal of organic pollutants: microwave power $(\mathrm{W})$, irradiation time $(\mathrm{min})$, and exposure temperature $\left({ }^{\circ} \mathrm{C}\right)$.

In complex treatment, the optimum dosages of oxidising agents and catalysts, $\mathrm{pH}$ values, and air supply parameters to the device must be determined. In addition to the influencing factors mentioned above, the light intensity and amount of oxygen in the solution are applied to photocatalysis and microwave photolysis reactions [70]. Thus, each specific organic contamination must determine the optimal values of these parameters of microwave exposure, depending on the required efficiency of destruction and mineralisation.

One urgent task of applying innovative oxidation methods is to optimise energy consumption, particularly when using microwaves. Hence, according to the authors [9], the least energy-intensive methods are $\mathrm{MW}+\mathrm{K}$ and $\mathrm{MW}+\mathrm{UV}+\mathrm{TiO}_{2}$; the most energyintensive is water treatment using only microwaves [60]. On the other hand, MW radiation in the pulsed mode significantly saves energy $[9,60]$.

The prospect of using MW in wastewater treatment is more justified in the presence of challenging organic substances that are not biodegradable.

Microwave irradiation has several practical uses, including the oxidation of synthetic dyes in the wastewater of industrial establishments in the textile, leather, cosmetic, food, paper, pharmaceutical, and other industries. In the presence of oxidants and catalysts, a $65-100 \%$ reduction in dye concentration can be achieved in 1.5-210 min at MW power of 150-900 W [73-75,77-80].

There is confirmation of successful MW oxidation of naphthenic acid, typical for industrial wastewater of oil-producing enterprises [81]. MW can be used for complex oxidation of wastewater containing ammonia [63], phosphorous compounds [65], phenols [9,62], pesticides [61], PAA [62], medical preparations [9], and other elements.

\subsection{Demulsification}

In many recently published papers on the subject of demulsification, we find information on MW destruction of two types of emulsions: (1) oil-in-water and (2) water-inoil $[82,83]$. In the first type, oil-in-water, the dispersive environment is water, and oil is a dispersed phase, fragmented in water in the form of individual droplets (direct emulsions). In the second type, water-in-oil, water is a dispersed phase in the form of individual droplets in the oil, a dispersive environment (reverse emulsions).

Highly concentrated oil-containing or petroleum-containing industrial WW from oil-producing and oil-refining enterprises falls into the first category, oil-in-water. Emulsion wastewater is also generated in the metallurgical and machine-building industries, including the processing of metals $[84,85]$. Used oil emulsions, water-based oil sludge, and other liquid waste containing more oils or petroleum products fall into the second category, water-in-oil [23,81,86-90].

The basic features and results of several laboratory studies on microwave intensification of the method of demulsification of industrial WW and WWS are described in Table 7. 
Table 7. Parameters and outcomes of several laboratory experiments on demulsification under the influence of MW.

\begin{tabular}{|c|c|c|c|c|c|c|}
\hline Emulsion Type & Water Content & Catalyst (C) & $\begin{array}{l}\text { MW Power and } \\
\text { Frequency }\end{array}$ & MW Duration & Results & [Ref./No] \\
\hline \multicolumn{7}{|c|}{ Waste water, sludge and oil-in-water emulsions: sample $+C+M W+60$ min settling } \\
\hline $\begin{array}{l}\text { Waste emulsions of the metallurgical } \\
\text { industry }\end{array}$ & No Data & $\begin{array}{c}\mathrm{NaOH}(6 \mathrm{M}) \\
\mathrm{HCl}(0.12-0.6 \mathrm{M})\end{array}$ & $\begin{array}{l}230-930 \mathrm{~W} \\
2.45 \mathrm{GHz}\end{array}$ & $1-4 \min$ & $65-90 \%$ & {$[84]$} \\
\hline $\begin{array}{l}\text { Waste oil water emulsions after } \\
\text { metalworking }\end{array}$ & $99 \%$ & Sea water $20 \%$ & $\begin{array}{c}700 \mathrm{~W} \\
2.45 \mathrm{GHz}\end{array}$ & $40 \mathrm{~s}$ & $92-93.2 \%$ & {$[85]$} \\
\hline \multicolumn{7}{|c|}{ Slurries, emulsions, and liquid waste of the water-in-oil type: sample $+\mathrm{C} /$ none $+\mathrm{MW}+50-70 \mathrm{~min}$ settling } \\
\hline Crude oil & $20(60) \%$ & none & $\begin{array}{c}700 \mathrm{~W} \\
2.45 \mathrm{GHz}\end{array}$ & $42 \mathrm{~s}$ & $\begin{array}{c}\text { Efficiency } 1 / \mathrm{td} \\
0.085(0.04)\end{array}$ & [82] \\
\hline Crude oil & $40-60 \%$ & $\begin{array}{c}\text { Sodium Acetate } 0.2 \\
\mathrm{M}\end{array}$ & $\begin{array}{l}360-450 \mathrm{~W} \\
2.45 \mathrm{GHz}\end{array}$ & $2-3 \min$ & $93-100 \%$ & {$[23,86]$} \\
\hline Crude oil & $50(20) \%$ & none & $\begin{array}{c}900 \mathrm{~W} \\
2.45 \mathrm{GHz}\end{array}$ & $\begin{array}{l}1-3.5 \mathrm{~min} \\
2-4.5 \mathrm{~min}\end{array}$ & $\begin{array}{l}85 \% \\
75 \% \\
\end{array}$ & [87] \\
\hline \multicolumn{7}{|c|}{ Low-temperature separation of emulsions } \\
\hline Oil/petroleum- emulsions & $30 \%$ & none & $\begin{array}{c}45 \mathrm{~W} \\
0.5 \mathrm{GHz}\end{array}$ & $10 \mathrm{~s}$ & $\begin{array}{l}\text { Visual enlargement of water } \\
\text { droplets in oil }\end{array}$ & {$[83]$} \\
\hline
\end{tabular}


The zeta potential at the interface decreases when MW is applied, and the viscosity of oils/oils decreases due to rapid heating, which is the reason for the accelerated separation of emulsions [86]. In addition, the presence of catalysts (alkalis, acids, salts, and other substances) accelerates the demulsification process, while the presence of anionic surfactants slows down the emulsion separation process [23,84-86]. The primary physical characteristics of MW heating were calculated after a thorough study of the heating effects of oil/oil-water emulsions associated with microwave resonance. It was found that the average power consumption decreases with a fall of the oil content in the oil-in-water emulsion and increases with a rise in the percentage of water in the water-in-oil emulsion [89].

Many authors emphasise that microwave irradiation is a relatively fast and, in general, cost-effective method for separating oil or petroleum products from wastewater $[84,85,89]$. Additionally, MW-demulsification of water-in-oil emulsions, common in slurries, is more effective and faster than traditional convective heating [23,82].

However, there are also some concerns. In the microwave treatment of oil sludge, the separation of the emulsion phases occurs mainly due to rapid heating, which requires sufficiently powerful MW generators [90]. In this instance, hydrocarbons are burned to form combustion products (gases), which is a significant drawback when choosing the MW method. It is also necessary to select the optimal MW power and processing time in each case [88].

Low-temperature microwave separation of oil emulsions has been studied and theoretically supported [83,90]. For example, the visible coalescence of oil droplets in the emulsion is observed at low power MW (up to $45 \mathrm{~W}$ ) with a period of only ten seconds [83]. In another scenario, oil globules were destroyed during the experimental MW processing of oil sludge samples with a power of only $2 \mathrm{~W}$ to $100 \mathrm{~W}$ for two to three minutes. According to one hypothesis, low-temperature emulsion separation occurs under some conditions due to the rupture of chemical bonds under the influence of an electromagnetic field, i.e., the "non-thermal effect" of microwaves [90].

In the future, it is necessary to conduct a study on the MW effective demulsification of oil containing WW from gas stations, service stations, and surface wastewater from highways.

\subsection{Extraction of Heavy Metals}

Metal ions are one of the most toxic and difficult to remove forms of WW and WWS contamination. Chemically bound elements are one of the causes. It will be easier to remove these pollutants from wastewater and sediments if they decompose quickly in water. One of the obstacles to using this waste as agro-fertilisers is heavy metal ions in the sediments.

Experimental microwave treatment of WW and WWS samples to decompose the substance and improve the efficiency of laboratory analysis of the components was stated in a critical review published in 1998 [91]. Microwave radiation in the presence of reagents increases the accuracy of atomic absorption spectrometry and cathodic stripping voltammetry measurements of metal ion concentrations $(\mathrm{Hg}, \mathrm{Cd}, \mathrm{Cr}, \mathrm{Cu}, \mathrm{Ni}, \mathrm{Pb}, \mathrm{Zn}, \mathrm{Bi}$, Sn, and others). This effect is explained by the decomposition of compounds with metals in liquid substances under the action of MW.

The possibilities of microwave preparation of wastewater samples for determining metal concentrations in real wastewater samples using atomic absorption and atomic emission spectrometry with inductively coupled plasma were shown in the article [92], which reflected this subject. Furthermore, microwave sample preparation was compared to conventional WW thermal mineralisation. The best results were obtained under conditions of acid treatment for aluminum (the determined ion concentration after microwave heating increased by 1.56 times compared to treatment in a thermal mineraliser), cadmium (by 2.58 times), and iron (by 1.22 times). With an installed power of $1000 \mathrm{~W}$ to $2000 \mathrm{~W}$, processing time in a domestic MW oven ranged from one to five minutes. 
However, there are not enough recent scientific publications that indicate the possibility of using microwaves to facilitate the extraction of metal ions from WW and WWS. The articles $[6,14]$ refer to changes in the properties of sewage sludge and the MW intensification of the release of metal ions into decanted water (Table 8). Results have been derived from batch experiments.

Table 8. The metal ions output into decanted water [6].

\begin{tabular}{cccc}
\hline \multirow{2}{*}{ Indicators } & \multicolumn{2}{c}{$\begin{array}{c}\text { Content of Metal Ions in Decanted Water, } \\
\text { mg/L }\end{array}$} & $\begin{array}{c}\text { Increase in } \\
\text { Concentration of } \\
\end{array}$ \\
\cline { 2 - 4 } & $\begin{array}{c}\text { without MW } \\
\text { Treatment }\end{array}$ & $\begin{array}{c}\text { Following MW } \\
\text { Processing }\end{array}$ & \\
\hline Arsenic & $<0.002$ & $0.004 \pm 0.002$ & 2 times \\
Nickel & $0.011 \pm 0.003$ & $0.020 \pm 0.006$ & 1.8 times \\
Mercury & $0.013 \pm 0.008$ & $0.017 \pm 0.010$ & 1.3 times \\
Lead & $0.002 \pm 0.001$ & $0.002 \pm 0.001$ & Not observed \\
Chrome $\left(6^{+}\right)$ & $0.114 \pm 0.0052$ & $0.218 \pm 0.100$ & 1.9 times \\
\hline
\end{tabular}

The yield of specific metal ions into decanted water (supernatant water) increases approximately 1.2-2 times after microwave treatment from five to ten minutes and subsequent compaction of a mixture of domestic WWS (raw sediment and activated sludge).

Other studies have also observed that the yield of heavy metal ions from WWS to water increases from 4 to 15\%, especially lead, zinc, and chromium [24].

This property can be used in the technological schemes of wastewater treatment plant (WWTP) as a pretreatment to intensify the further release of heavy metal ions from wastewater and its sediments.

\subsection{Biogas Processing}

European and Asian experience in managing liquid municipal waste gives preference to the anaerobic treatment of wastewater and sediments to produce biogas. The maximum number of biogas plants operate in China-approximately fifteen million, and India-about ten million. The construction of biogas plants is actively developing in Europe, especially in Germany, with more than 9000 stations. Only 7\% of the biogas produced by these enterprises goes to the gas pipelines. The rest is used for the manufacturer's needs. In the future, $10-20 \%$ of the natural gas used in the country can be replaced with biogas [93-95].

The biogas market is growing much more slowly in countries with natural gas resources. For example, only about 200 biogas plants operate on agricultural waste in the United States [95]. In Russia, the production of biogas is implemented in only a few WWTP [96].

Today, the anaerobic treatment of wastewater and sediments to produce biogas guarantees fuel and energy savings. However, there are problems related to the quality of the treated material, the provision of conditions for the stability of the biodegradation of organic matter, and the explosion hazard of biogas production [97,98].

Microwaving is a novel thermal pretreatment process for sludges that improves digestion efficiency and, under certain conditions, can intensify the gas output by $15-32 \%$ due to the solubilisation and hydrolysis of organic substances [99-105]. Previous studies have shown that MW pretreatment is more effective for sludge with a high concentration of solid particles [101,102]. It is also proved that in the thermophilic fermentation mode, the yield of biogas from the MW-treated sediment is higher than in the mesophilic mode [99]. The results of modern studies based on $[99,106]$ are presented in Table 9. 
Table 9. Intensification of the biogas output during the MW treatment of WWS.

\begin{tabular}{|c|c|c|c|c|c|}
\hline Sediment & MW Power and Frequency & Temperature & Sample Processing Conditions & Description of Results & [Ref./No] \\
\hline $\begin{array}{l}\text { Domestic wastewater sludge } \\
\text { mixture, ratio } 48: 52\end{array}$ & $\begin{array}{l}1250 \mathrm{~W} \\
2.45 \mathrm{GHz}\end{array}$ & $96^{\circ} \mathrm{C}$ & $\begin{array}{l}500 \mathrm{~mL} \text { samples heated in a home MW } \\
\text { furnace to the boiling point, then subjected } \\
\text { to anaerobic digestion in laboratory reactors } \\
\text { for } 5-18 \text { days; biogas output recorded. }\end{array}$ & $\begin{array}{l}\text { With thermophilic } \\
\text { fermentation, the gas } \\
\text { output increased by } \\
17-26 \% \text {. }\end{array}$ & [99] \\
\hline Dehydrated WWS & $\begin{array}{l}1200 \mathrm{~W} \\
2.45 \mathrm{GHz}\end{array}$ & $80-160^{\circ} \mathrm{C}$ & $\begin{array}{l}\text { Samples heated and kept at a set } \\
\text { temperature for } 1 \mathrm{~min} \text {, then cooled for } 25 \\
\text { min. Heating speed } 7.5^{\circ} \mathrm{C} / \mathrm{min} \text {. Further, the } \\
\text { samples were subjected to anaerobic } \\
\text { digestion in laboratory reactors for } 5-20 \\
\text { days; biogas output was recorded. }\end{array}$ & $\begin{array}{l}\text { Maximal biogas output: At } \\
160^{\circ} \mathrm{C} \text { - on the fifth day of the } \\
\text { fermentation process. At } 120 \\
{ }^{\circ} \mathrm{C} \text { on the tenth day. }\end{array}$ & [105] \\
\hline Sludge mixture & $\begin{array}{c}300-600 \mathrm{~W} \\
2.45 \mathrm{GHz}\end{array}$ & no data & $\begin{array}{l}\text { Microwave pre-treatments were carried out } \\
\text { in a semi-pilot MW unit in which the flow } \\
\text { rate varied in the range of } 5-60 \mathrm{~L} / \mathrm{h} \text {. Next, } \\
\text { anaerobic digestion of the nitrogen-treated } \\
\text { sludge mixture was carried out at a } \\
\text { temperature of } 37 \text { degrees. }\end{array}$ & $\begin{array}{l}\text { The biogas production } \\
\text { improved by } 174-210 \% \\
\text { (depending on the MW } \\
\text { power and irradiated energy) }\end{array}$ & [106] \\
\hline
\end{tabular}




\subsection{Pyrolysis of Wastewater Sludge}

Pyrolysis is currently considered to be the most promising WWS disposal technology. The benefit of this approach is that it produces transportation-friendly fuel that can also be used to generate thermal and electrical energy. It also enables biomass to be converted into combustible gas, coal, liquid synthetic fuel, and chemical raw materials. Moreover, the waste from the process can be turned into an environmentally friendly granular glazed product for road building and the construction supply industry [107-109].

Pyrolysis, also known as dry distillation, is the thermal treatment of sewage sludge or other carbon-containing waste by high-temperature $\left(450-800^{\circ} \mathrm{C}\right)$ or low-temperature $\left(200-400{ }^{\circ} \mathrm{C}\right)$ heating without air access. As a result of such process, about $50 \%$ of solid residues (coal, charred coal, and pyrocarbon), about $20-32 \%$ of liquid products similar in quality to crude oil (tar or primary tar-bio-oil), and $12-15 \%$ of a combination of gaseous products (biogas) are obtained. Pyrocarbon and bio-oil are the most valuable pyrolysis products. In the 1980s, more than 300 pilot plants for pyrolysis of precipitation, including those that mixed solid waste and industrial waste, were built in the United States, Germany, Italy, and Japan. However, owing to economic infeasibility and technical flaws, many of them were eventually shut down [107].

Microwave pyrolysis is a promising method for the thermochemical conversion of dehydrated sewage sludge into usable energy products, including bio-carbon, bio-oil, and biogas. However, there are not many publications on this subject. The article [107] provides an overview of the latest research on traditional and microwave pyrolysis heating. It compares alternate approaches, examines pyrolysis products, and discusses the pros and cons of using microwaves for pyrolysis of WWS. The structure of the residues, MW parameters, laboratory conditions, and catalyst forms all influence the efficiency and properties of microwave pyrolysis products.

When microwaving just the raw sample of sludge, it only dries. However, adding a small amount of a microwave absorber to the sample (such as the char produced during pyrolysis) leads to pyrolysis rather than drying [109].

\subsection{Modification of Sorbents}

Assuring sorption products for wastewater treatment should have high sorption properties and be non-toxic, regenerable, easily disposed of, low-cost; and an affordable raw material base. Natural materials' major weakness as sorbents is their poorly expressed sorption potential, which is also affected by their increased hydrophilicity. Reducing water absorption and increasing sorption activity can be achieved by various modifications [110].

Some inorganic sorption products, such as clays, natural zeolites, and active coals, have been shown to have increased basic surface area, porosity, and availability of functional groups after MW treatment. Microwave exposure may otherwise result in a degradation in the properties of coals due to the decrease in permeability [111]. Microwave radiation seems to accelerate many chemical reactions by dozens of times, promotes rapid volumetric heating of liquid and solid samples, and wholly and quickly removes moisture [112], which is vital in sorbents' production.

The best findings for MW treatment of sorbents based on natural materials used for wastewater treatment (frequency $\mathrm{f}=2.45 \mathrm{GHz}$ ) can be found in Table 10 . 
Table 10. Results of MW processing of sorbents based on natural materials.

\begin{tabular}{|c|c|c|c|c|c|c|}
\hline Sorbent & $\begin{array}{c}\text { Sorbent Preparation } \\
\text { Process }\end{array}$ & MW Power & Duration & Temperature & Description of Results & [Ref./No] \\
\hline Peat & MW heat & $60-600 \mathrm{~W}$ & $60 \mathrm{~min}$ & No data & $\begin{array}{c}\text { Oil capacity } 2.5-2.73 \mathrm{~g} / \mathrm{g} \text {. } \\
\text { With increasing power, the adsorption of iodine increases by } \\
1.2-1.4 \text { times (from } 115 \text { to } 150 \mathrm{mg} / \mathrm{g} \text { ), and for methylene blue } \\
\text { it decreases by } 2 \text { times (from } 55 \text { to } 28 \mathrm{mg} / \mathrm{g} \text { ) }\end{array}$ & [113] \\
\hline Peat & MW heat & $900 \mathrm{~W}$ & $12 \mathrm{~min}$ & $450^{\circ} \mathrm{C}$ & Iodine adsorption activity increased from $11.4 \%$ to $19.1 \%$ & [114] \\
\hline Brown coal & MW heat & $900 \mathrm{~W}$ & $22.5 \mathrm{~min}$ & $315^{\circ} \mathrm{C}$ & Iodine adsorption activity increased from $18.0 \%$ to $34.9 \%$ & [114] \\
\hline Pine sawdust & $\begin{array}{l}\text { Grinding, drying and } \\
\text { MW heat }\end{array}$ & $600 \mathrm{~W}$ & $2 \mathrm{~min}$ & $40^{\circ} \mathrm{C}$ & $\begin{array}{l}\text { Increase in the sorption capacity for petroleum products by } \\
\quad 3.7-4 \text { times } \\
\text { for initial concentrations of less than } \\
5 \mathrm{mg} / \mathrm{L} \text { and by } 1.2 \text { times for initial } \\
\text { concentrations of } 16-35 \mathrm{mg} / \mathrm{L}\end{array}$ & [110] \\
\hline Rice husk & $\begin{array}{l}\text { Combustion in the MW } \\
\text { furnace }\end{array}$ & No data & $\begin{array}{l}288 \mathrm{~h} \\
384 \mathrm{~h}\end{array}$ & $\begin{array}{l}500{ }^{\circ} \mathrm{C} \\
800{ }^{\circ} \mathrm{C}\end{array}$ & $\begin{array}{c}\text { Removal of petroleum products: } \\
78 \% \\
98 \%\end{array}$ & [116] \\
\hline
\end{tabular}


Intensified combined process of dye adsorption and decomposition is experienced using a hybrid catalyst $\mathrm{rGO}-\mathrm{TiO}_{2}$. The thermal mechanism of action on materials, especially carbon-based, is studied in the article [80]. This process consists of local MW heating of the area close to the catalyst's surface, which leads to the accumulation of heat on it, i.e., the creation of "hot spots" on the exterior, allowing processing speed to be increased.

A newly developed method for sorbent regeneration [117] is carried out in a resonant container with the addition of MW, which is only used to break the intermolecular bonds between the sorbent and the sorbate and does not result in thermal heating of the substances.

Several authors prove $[73,118,119]$ that the microwave effect on sorption materials allows one to achieve an increase in their sorption activity and specific surface area, to reduce water absorption due to a uniform and rapid effect on the material, which reduces the time and simplifies the processing method and, accordingly, reduces material costs.

Still, there are the following main limitations of the use of microwave irradiation in sorbent preparation technologies: an increase in energy costs; the absence of industrialscale magnetrons; and, due to the limited depth of penetration of microwaves into the material of solid sorbents, small volumes are subject to processing [116].

However, the introduction of microwave processing will provide environmentally friendly methods for the preparation of sorbing materials for wastewater treatment; efficient and economical intensification of the processes of sorption of pollutants; and minimal negative impact on the environment due to the reduction of reagents used at the stages of modification, regeneration, and activation of sorbents.

\subsection{Devices for MW-Processing of WW and WWS}

One of the problems with the widespread scaling of MW wastewater and sludge treatment is the lack of unified high-performance industrial reactors on the market that are adapted for municipal needs. MW plants (installations/devices/reactors) for liquid waste treatment are experimental equipment designed to handle small volumes.

Many scientists conduct experiments in home microwave ovens or reactors based on them or in modular laboratory systems $[8,14,36,90,108,110]$.

The data obtained from a patent search in the Russian database for MW installations/devices intended or possible for the treatment of wastewater and its sediments are presented below (Table 11). 
Table 11. MW installations/devices intended (or possible for use) for wastewater and sediments treatment (Russia).

\begin{tabular}{|c|c|c|c|c|c|c|c|c|}
\hline \multirow[t]{2}{*}{ Device/Installation } & \multicolumn{2}{|c|}{$\begin{array}{l}\text { Application } \\
\text { Domain: } \\
\text { Treatment of }\end{array}$} & \multicolumn{2}{|c|}{ Type of Action } & \multirow{2}{*}{$\begin{array}{c}\text { Parameters: Power } \mathrm{N}, \\
\text { Frequency } \mathrm{F}, \\
\text { Throughput } \mathrm{Q}, \\
\text { Temperature } \mathrm{T}\end{array}$} & \multirow[t]{2}{*}{$\begin{array}{l}\text { Patent Number, } \\
\text { (Year) }\end{array}$} & \multirow[t]{2}{*}{ MW Process Setting } & \multirow[t]{2}{*}{ [Ref./No] } \\
\hline & WW & WWS & $1 *$ & $2 *$ & & & & \\
\hline $\begin{array}{l}\text { Sewage treatment } \\
\text { installation }\end{array}$ & + & - & - & + & No Data & RU 116851 (2012) & $\begin{array}{l}\text { Combined UV and MW water } \\
\text { disinfection }\end{array}$ & [120] \\
\hline $\begin{array}{l}\text { Industrial and domestic } \\
\text { sewage handling } \\
\text { equipment }\end{array}$ & - & + & + & - & $\begin{array}{l}\text { T } 430-1000{ }^{\circ} \mathrm{C} \\
\quad \text { f } 2.5 \mathrm{GHz}\end{array}$ & $\begin{array}{l}\text { RU } 2552259 \\
\quad(2015)\end{array}$ & $\begin{array}{l}\text { Decomposition of waste under the } \\
\text { combined influence of thermal and } \\
\text { electromagnetic fields without } \\
\text { oxygen access }\end{array}$ & [121] \\
\hline Waste incineration chamber & - & + & + & - & T $1200-1400{ }^{\circ} \mathrm{C}$ & $\begin{array}{c}\text { RU } 2573137 \\
\text { (2016) }\end{array}$ & $\begin{array}{l}\text { Heating of the disposed waste to the } \\
\text { combustion temperature }\end{array}$ & [122] \\
\hline $\begin{array}{l}\text { Sewage sludge MW } \\
\text { treatment plant }\end{array}$ & - & + & - & + & $\begin{array}{l}\text { N } 5440 \mathrm{~W} \\
\text { Q } 1.37 \mathrm{t} / \mathrm{h}\end{array}$ & $\begin{array}{l}\text { RU } 2582415 \\
\text { (2016) }\end{array}$ & $\begin{array}{l}\text { Disinfection of industrial, domestic, } \\
\text { and agricultural sewage sludge }\end{array}$ & [123] \\
\hline $\begin{array}{l}\text { Wastewater and sediments } \\
\text { MW treatment and } \\
\text { decontamination device }\end{array}$ & + & + & - & + & $\begin{array}{l}\text { N } 2000 \mathrm{~W} \\
\text { f } 2.45 \mathrm{GHz} \\
\text { Q } 0.1 \mathrm{~m}^{3} / \mathrm{h} \\
\text { T } 50-85^{\circ} \mathrm{C}\end{array}$ & $\begin{array}{l}\text { RU } 2693783 \\
\quad(2019)\end{array}$ & $\begin{array}{l}\text { MW pretreatment of sediments prior } \\
\text { to anaerobic fermentation }\end{array}$ & [124] \\
\hline $\begin{array}{l}\text { Anaerobic processing plant } \\
\text { for liquid organic waste }\end{array}$ & - & + & + & - & $\mathrm{T} 60-70{ }^{\circ} \mathrm{C}$ & $\begin{array}{l}\text { RU } 2687415 \\
\quad(2019)\end{array}$ & $\begin{array}{l}\text { MW pretreatment of WWS prior to } \\
\text { anaerobic fermentation }\end{array}$ & [125] \\
\hline $\begin{array}{l}\text { Electromagnetic phase } \\
\text { separation system for } \\
\text { oil-water emulsion }\end{array}$ & - & + & - & + & f $2.45 \mathrm{GHz}$ & $\begin{array}{l}\text { RU } 2710181 \\
\quad(2019)\end{array}$ & $\begin{array}{c}\text { Destruction of oil-water emulsions } \\
\text { (sludge from oil fields and oil } \\
\text { refineries) }\end{array}$ & [126] \\
\hline $\begin{array}{l}\text { Wastewater treatment by } \\
\text { irradiation with } \\
\text { ultra-high-frequency waves } \\
\text { and ultraviolet light plant }\end{array}$ & + & - & - & + & No Data & $\begin{array}{l}\text { RU } 193171 \text { U1 } \\
\text { (2019) }\end{array}$ & $\begin{array}{c}\text { Combined UV and MW wastewater } \\
\text { disinfection }\end{array}$ & [127] \\
\hline $\begin{array}{l}\text { MW mobile technological } \\
\text { complex treatment of acid } \\
\text { mine water }\end{array}$ & + & - & + & - & $\begin{array}{l}\text { N } 1000 \mathrm{~W} \\
\text { f } 1.38 \mathrm{GHz} \\
\text { Q } 150 \mathrm{~m}^{3} / \mathrm{h}\end{array}$ & $\begin{array}{l}\text { RU } 2739259 \\
\quad(2020)\end{array}$ & $\begin{array}{l}\text { MW is used to transfer ionic and } \\
\text { molecular components to the } \\
\text { condensed phase and remove them } \\
\text { from the treated water }\end{array}$ & {$[128]$} \\
\hline
\end{tabular}




\section{Conclusions and Considerations for Future Research}

Currently, the search for effective and economical methods for wastewater and its sediments treatment continues. As the gathered review showed, there is much more research on microwave radiation to manage wastewater and sediments. Microwave treatment of such liquid municipal and industrial waste is of interest primarily because of the rapid heating and improvement of the properties of the treated materials, which reduce the time of their stay in the facilities and increase the productivity and the efficiency of the equipment. Moreover, microwaves' decontaminating effect opens up a world of possibilities for using this process in the context of a pandemic.

Table 12 summarises the opportunities for practical implementation of MW in WW and WWS treatment technologies in different areas of human economic and industrial activities.

Table 12. The opportunities for practical implementation of MW in wastewater and sludge treatment technologies.

\begin{tabular}{|c|c|c|}
\hline No & Practical Application Field & $\begin{array}{l}\text { Promising Areas of Practical Application of MW in } \\
\text { Wastewater and Wastewater Sludge Treatment Technologies }\end{array}$ \\
\hline 1. & Municipal local services & $\begin{array}{l}\text { Wastewater treatment of all types (reduction of organic matter } \\
\text { concentration, improvement of coagulation processes, and } \\
\text { decomposition of chemicals), wastewater sludge treatment } \\
\text { (reduction of volumes and organic matter content), an increase } \\
\text { of biogas production during wastewater sludge fermentation } \\
\text { on an urban spit, disinfection of all forms of wastewater and } \\
\text { wastewater sludge, and intensification of pyrolysis and } \\
\text { production of secondary raw materials }\end{array}$ \\
\hline 2. & Production of drinking water & $\begin{array}{l}\text { Water disinfection. Treatment of water sludge in order to } \\
\text { reduce the volume, reducing the organic component }\end{array}$ \\
\hline 3. & Agricultural industry & $\begin{array}{l}\text { Improvement of biogas output in the fermentation of manure, } \\
\text { sewage sludge, and other liquid industrial waste; } \\
\text { decontamination of all types of wastewater and sediments; and } \\
\text { decomposition of pesticides in surface wastewater }\end{array}$ \\
\hline 4. & Medical institutions, pharmaceutical industry & $\begin{array}{l}\text { Disinfection of all types of wastewater and waste; } \\
\text { decomposition of medicines in wastewater and sediments }\end{array}$ \\
\hline 5. & Metallurgical industry and machine-building & $\begin{array}{l}\text { Industrial wastewater coagulation, extraction of metals from } \\
\text { wastewater and sediments }\end{array}$ \\
\hline 6. & Oil and petroleum industry & $\begin{array}{c}\text { Demulsification of oil-water emulsions and oil-containing } \\
\text { industrial wastewater, decomposition and reduction of oil } \\
\text { sludge volumes }\end{array}$ \\
\hline 7. & Dairy industry & $\begin{array}{l}\text { Organic matter oxidation in industrial wastewater, sludge } \\
\text { treatment to reduce volumes and organic matter, and } \\
\text { decontamination of all types of wastewater and sludge }\end{array}$ \\
\hline 8. & Chemical industry & $\begin{array}{l}\text { New substances synthesis; chemical decomposition in } \\
\text { industrial wastewater and sediments }\end{array}$ \\
\hline 9. & Textile industry & $\begin{array}{l}\text { Dye decomposition in industrial wastewater, improving the } \\
\text { coagulation of contaminants; decontamination of all types of } \\
\text { wastewater and sludge }\end{array}$ \\
\hline 10. & Recycling and disposal of industrial waste & $\begin{array}{l}\text { Decomposition of chemical, organic, and radioactive substances; } \\
\text { reduction of liquid waste; and decontamination }\end{array}$ \\
\hline 11. & Sorbent manufacture & $\begin{array}{c}\text { Modification, regeneration, and activation of phyto-sorbents for } \\
\text { sewage purification }\end{array}$ \\
\hline
\end{tabular}

Nevertheless, along with the broad prospects for the global practical relevance of microwaves in wastewater and wastewater sludge treatment, the main problems remain the lack of universal technologies and industrial equipment, small volumes, and high energy consumption. At the same time, almost all studies do not go beyond the laboratories and 
usually relate to specific environments (water and sludge samples) and require verification and confirmation for a wide scale.

The lack of high-performance, high-efficiency, and energy-saving industrial MW reactors designed to treat liquid municipal and industrial waste is a concern. The future universal reactor must operate in the flow mode, be able to automatically change the MW parameters depending on the quality of the initial flow, and have reliable human protection from residual microwave irradiation during the process.

Author Contributions: Conceptualization, E.V.; methodology, E.V., M.O. and L.B.; formal analysis, E.V.; investigations, E.V., M.O. and L.B.; data curation, E.V., M.O. and L.B.; writing-original draft preparation, E.V., M.O. and L.B.; writing-review and editing, E.V., M.O. and L.B..; visualization, E.V., M.O. and L.B.; supervision, E.V.; project administration, E.V.; funding acquisition, E.V. All authors have read and agreed to the published version of the manuscript.

Funding: The article is published with the grant support of the Industrial University of Tyumen (Contract №4179/NPK, 10.12.2020).

Institutional Review Board Statement: The study did not involve humans or animals.

Informed Consent Statement: Not applicable.

Data Availability Statement: The data presented in this study are available on request from the corresponding author.

Acknowledgments: Authors acknowledge any administrative and technical support given by Kropcheva S.N.

Conflicts of Interest: The authors declare no conflict of interest. The funders had no role in the design of the study, in the collection, analyses, or interpretation of data, in the writing of the manuscript; or in the decision to publish the results.

\section{References}

1. Priroda, S.U. Nature, Ecology and Environment. Available online: http:/ / priroda.su/ (accessed on 4 May 2021).

2. Harris, P.W.; McCabe, B.K. Review of pre-treatments used in anaerobic digestion and their potential application in high-fat cattle slaughterhouse wastewater. Appl. Energy 2015, 155, 560-575. [CrossRef]

3. Tyagi, V.; Lo, S.-L. Microwave irradiation: A sustainable way for sludge treatment and resource recovery. Renew. Sustain. Energy Rev. 2013, 18, 288-305. [CrossRef]

4. Zhen, G.; Lu, X.; Kato, H.; Zhao, Y.; Li, Y.-Y. Overview of pretreatment strategies for enhancing sewage sludge disintegration and subsequent anaerobic digestion: Current advances, full-scale application and future perspectives. Renew. Sustain. Energy Rev. 2017, 69, 559-577. [CrossRef]

5. Elagroudy, S.; El-Gohary, F. Microwave Pretreatment of Mixed Sludge for Anaerobic Digestion Enhancement. Environ. Eng. 2013, 5, 105-111. [CrossRef]

6. Kichigin, V.; Samara State Technical University; Zemlyanova, M.; Vyalkova, E.; Tumen State Industrial University. Study of the Possibility of Using Microwave Radiation for the Treatment of Liquid Municipal Waste. Urban Constr. Arch. 2018, 8, 44-49. [CrossRef]

7. Mudhoo, A.; Sharma, S.K.; Sharma, S.K. Microwave Irradiation Technology in Waste Sludge and Wastewater Treatment Research. Crit. Rev. Environ. Sci. Technol. 2011, 41, 999-1066. [CrossRef]

8. Wiesbrock, F.; Hoogenboom, R.; Schubert, U.S. Microwave-Assisted Polymer Synthesis: State-of-the-Art and Future Perspectives. Macromol. Rapid Commun. 2004, 25, 1739-1764. [CrossRef]

9. Remya, N.; Lin, J.-G. Current status of microwave application in wastewater treatment-A review. Chem. Eng. J. 2011, 166, 797-813. [CrossRef]

10. Gole, V.L.; Gogate, P.R. Degradation of brilliant green dye using combined treatment strategies based on different irradiations. Sep. Purif. Technol. 2014, 133, 212-220. [CrossRef]

11. Herrero, M.A.; Kremsner, J.M.; Kappe, C.O. Nonthermal Microwave Effects Revisited: On the Importance of Internal Temperature Monitoring and Agitation in Microwave Chemistry. J. Org. Chem. 2008, 73, 36-47. [CrossRef]

12. Yang, L.; Chen, Z.; Yang, J.; Liu, Y.; Wang, J.; Yu, Y.; Gao, X. Removal of volatile fatty acid in landfill leachate by the microwavehydrothermal method. Desalination Water Treat. 2013, 52, 4423-4429. [CrossRef]

13. Wei, R.; Wang, P.; Zhang, G.; Wang, N.; Zheng, T. Microwave-responsive catalysts for wastewater treatment: A review. Chem. Eng. J. 2020, 382, 122781. [CrossRef]

14. Vialkova, E.; Zemlyanova, M.; Danilov, O. Energy efficiency in municipal waste treatment. MATEC Web Conf. 2018, 170, 04020. [CrossRef] 
15. Hidaka, H.; Saitou, A.; Honjou, H.; Hosoda, K.; Moriya, M.; Serpone, N. Microwave-assisted dechlorination of polychlorobenzenes by hypophosphite anions in aqueous alkaline media in the presence of Pd-loaded active carbon. J. Hazard. Mater. 2007, 148, 22-28. [CrossRef] [PubMed]

16. Kappe, C.O. Controlled Microwave Heating in Modern Organic Synthesis. Angew. Chem. Int. Ed. 2004, 43, 6250-6284. [CrossRef]

17. Mishra, R.R.; Sharma, A.K. Microwave-material interaction phenomena: Heating mechanisms, challenges and opportunities in material processing. Compos. Part A Appl. Sci. Manuf. 2016, 81, 78-97. [CrossRef]

18. Clark, D.E.; Folz, D.C.; West, J.K. Processing materials with microwave energy. Mater. Sci. Eng. A 2000, 287, 153-158. [CrossRef]

19. Horikoshi, S.; Serpone, N. Photochemistry with microwaves: Catalysts and environmental applications. J. Photochem. Photobiol. C Photochem. Rev. 2009, 10, 96-110. [CrossRef]

20. Baghurst, D.R.; Mingos, D.M.P. Superheating effects associated with microwave dielectric heating. J. Chem. Soc. Chem. Commun. 1992, 674-677. [CrossRef]

21. Gabriel, C.; Gabriel, S.; Grant, E.H.; Halstead, B.S.J.; Mingos, D.M.P. Dielectric parameters relevant to microwave dielectric heating. Chem. Soc. Rev. 1998, 27, 213-224. [CrossRef]

22. Zhang, L.; Guo, X.; Yan, F.; Su, M.; Li, Y. Study of the degradation behaviour of dimethoate under microwave irradiation. J. Hazard. Mater. 2007, 149, 675-679. [CrossRef] [PubMed]

23. Akbari, S.; Nour, A.; Jamari, S.; Rajabi, A. Demulsification of Water-in-Crude Oil Emulsion via Conventional Heating and Microwave Heating Technology in Their Optimum Conditions. Aust. J. Basic Appl. Sci. 2016, 10, 66-74.

24. Vialkova, E.; Zemlyanova, M.; Fugaeva, A. Treatment and utilization of liquid communal waste in the cities. MATEC Web Conf. 2018, 212, 03005. [CrossRef]

25. Yu, Q.; Lei, H.; Li, Z.; Li, H.; Chen, K.; Zhang, X.; Liang, R. Physical and chemical properties of waste-activated sludge after microwave treatment. Water Res. 2010, 44, 2841-2849. [CrossRef] [PubMed]

26. Mawioo, P.M.; Rweyemamu, A.; Garcia, H.A.; Hooijmans, C.M.; Brdjanovic, D. Evaluation of a microwave based reactor for the treatment of blackwater sludge. Sci. Total Environ. 2016, 548-549, 72-81. [CrossRef]

27. Mawioo, P.M.; Hooijmans, C.M.; Garcia, H.A.; Brdjanovic, D. Microwave treatment of faecal sludge from intensively used toilets in the slums of Nairobi, Kenya. J. Environ. Manag. 2016, 184, 575-584. [CrossRef] [PubMed]

28. Tigyi, J.; Masszi, G.; Koszorus, L. A Simple Microwave Argument about the Changes of Structure of Water in Solutions of Macromolecules. In Interactions of Water in Ionic and Nonionic Hydrates; Springer: Berlin/Heidelberg, Germany, 1987; pp. 195-198.

29. Chaplin, M. A proposal for the structuring of water. Biophys. Chem. 2000, 83, 211-221. [CrossRef]

30. Asakuma, Y.; Kanazawa, Y.; Parmar, H.; Phan, C.; Pareek, V.; Evans, G. Surface Tension Profiles under Various Microwave Radiation Modes. J. Energy Power Eng. 2014, 8, 585-588.

31. Parmar, H.; Asada, M.; Kanazawa, Y.; Asakuma, Y.; Phan, C.M.; Pareek, V.; Evans, G.M. Influence of Microwaves on the Water Surface Tension. Langmuir 2014, 30, 9875-9879. [CrossRef]

32. Asakuma, Y.; Munenaga, T.; Nakata, R. Observation of bubble formation in water during microwave irradiation by dynamic light scattering. Heat Mass Transf. 2016, 52, 1833-1840. [CrossRef]

33. Wong, T.W.; Iskhandar, A.; Kamal, M.; Jumi, S.J.; Kamarudin, N.H.; Zin, N.Z.M.; Salleh, N.H.M. Effects of Microwave on Water and Its Influence on Drug Dissolution. Prog. Electromagn. Res. C 2009, 11, 121-136. [CrossRef]

34. Zemlyanova, M.V. Intensification of Household Wastewater Sludge Treatment by Ultra-High Frequency Electromagnetic Radiation. Ph.D. Thesis, Samarskiy Gosudarstvennyy Arkhitekturno-Stroitel'nyy Universitet, Samara, Russia, 2015. Available online: http:/ / www.dslib.net/vodosnabzhenie/intensifikacija-processov-obrabotki-osadkov-gorodskih-stochnyh-vod-s-pomowju. html (accessed on 3 May 2021).

35. Zhang, J.; Pang, Q.; He, Z.; Tian, C.; Wu, T. Treatment of Blast Furnace Gas Washing Water by Utilization of Coagulation Associated with Microwave. In Applications of Process Engineering Principles in Materials Processing, Energy and Environmental Technologies; Wang, S., Free, M.L., Alam, S., Zhang, M., Taylor, P.R., Eds.; Springer International Publishing: Cham, Switzerland, 2017; pp. 555-563.

36. Zemlyanova, M.; Vialkova, E. Investigation of Combined Influence of Super-High-Frequency Electromagnetic Radiation on the Sewage Sediment Properties. Ecol. Ind. Russ. 2018, 22, 20-25. [CrossRef]

37. Liu, J.; Wei, Y.; Li, K.; Tong, J.; Wang, Y.; Jia, R. Microwave-acid pretreatment: A potential process for enhancing sludge dewaterability. Water Res. 2016, 90, 225-234. [CrossRef] [PubMed]

38. Wojciechowska, E. Application of microwaves for sewage sludge conditioning. Water Res. 2005, 39, 4749-4754. [CrossRef]

39. Doğan, I.; Sanin, F.D. Alkaline solubilization and microwave irradiation as a combined sludge disintegration and minimization method. Water Res. 2009, 43, 2139-2148. [CrossRef] [PubMed]

40. Zhou, C.; Chang, J.; Chen, J.; Kong, H. Impacts of Microwave on Dewater Ability and Morphological Feature of Sewage Sludge. J. Civ. Archit. Environ. Eng. 2013, 35, 135-139. [CrossRef]

41. Mawioo, P.M.; Garcia, H.A.; Hooijmans, C.M.; Velkushanova, K.; Simonič, M.; Mijatović, I.; Brdjanovic, D. A pilot-scale microwave technology for sludge sanitization and drying. Sci. Total Environ. 2017, 601-602, 1437-1448. [CrossRef]

42. Rao, B.; Su, X.; Lu, X.; Wan, Y.; Huang, G.; Zhang, Y.; Xu, P.; Qiu, S.; Zhang, J. Ultrahigh pressure filtration dewatering of municipal sludge based on microwave pretreatment. J. Environ. Manag. 2019, 247, 588-595. [CrossRef]

43. Makarov, P.O. Biophysical Bases of the Action of Ultraviolet and Ultrasonic Radiation and Ultrahigh-Frequency Electromagnetic Field. Lectures on Biophysics; LSU Publishing House: Leningrad, Russia, 1968; pp. 209-233. 
44. Devyatkov, N.D. Influence of Millimeter-band Electromagnetic Radiation on Biological Objects. Sov. Phys. Uspekhi 1974, 16, 568-569. [CrossRef]

45. Belitsky, B.I. Study of the effect of the microwave field on microorganisms in pulse and continuous mode. Biophysics 1982, 27, 923-927.

46. Panasenko, V.I. The Effect of a Powerful EMF with a Frequency of $2375 \mathrm{Mhz}$ on Microorganisms. Biological Effect of Electromagnetic Fields; USSR: Pushchino, Russia, 1982; pp. 26-27.

47. Benjamin, E.; Reznik, A.; Williams, A.L. Mathematical Models for Conventional and Microwave Thermal Deactivation of Enterococcus Faecalis, Staphylococcus aureus and Escherichia coli. Cell Mol. Biol. 2007, 53, 42-48.

48. Rosenberg, H.C. System for Purifying Liquids. U.S. Patent 4013558A, 22 March 1977.

49. Zabolotskij, L.L.; Klimarev, S.I.; Lobanov, A.G. Device for Disinfection and Heating of Aqueous Media. Patent SU1139439A1, 1985.

50. Klimarev, S.I.; Grigorev, A.A.; Sinyak, Y.E. Method for Liquids Disinfection and Heating, and Device for Its Implementation. Russian Patent RU2627899, 14 August 2017.

51. Ahmedova, O.O.; Stepanov, S.F.; Soshinov, A.G.; Bahtiarov, K.H. Increase of Efficiency of Local Treatment Facilities of Sewage for the Account of Application of the Combined Electrophysical Methods of Influence. Mod. Probl. Sci. Educ. 2009, 5, 56-60.

52. Karlsson, M.; Carlsson, H.; Idebro, M.; Eek, C. Microwave Heating as a Method to Improve Sanitation of Sewage Sludge in Wastewater Plants. IEEE Access 2019, 7, 142308-142316. [CrossRef]

53. Ara, E.; Sartaj, M.; Kennedy, K. Effect of microwave pre-treatment of thickened waste activated sludge on biogas production from co-digestion of organic fraction of municipal solid waste, thickened waste activated sludge and municipal sludge. Waste Manag. Res. 2014, 32, 1200-1209. [CrossRef]

54. Kenge, A.; Liao, P.H.; Lo, K.V. Solubilization of municipal anaerobic sludge using microwave-enhanced advanced oxidation process. J. Environ. Sci. Health Part A 2009, 44, 502-506. [CrossRef]

55. Hong, S.M.; Park, J.K.; Teeradej, N.; Lee, Y.O.; Cho, Y.K.; Park, C.H. Pretreatment of Sludge with Microwaves for Pathogen Destruction and Improved Anaerobic Digestion Performance. Water Environ. Res. 2006, 78, 76-83. [CrossRef] [PubMed]

56. Kuglarz, M.; Karakashev, D.B.; Angelidaki, I. Microwave and thermal pretreatment as methods for increasing the biogas potential of secondary sludge from municipal wastewater treatment plants. Bioresour. Technol. 2013, 134, 290-297. [CrossRef] [PubMed]

57. Worthington, P. Organic Micropollutants in the Aqueous Environment. In Studies in Environmental Science; Pawlowski, L., Alaerts, G., Lacy, W.J., Eds.; Chemistry for Protection of the Environment 1985; Elsevier: Amsterdam, The Netherlands, 1986; Volume 29, pp. 235-244.

58. Randtke, S.J. Organic Contaminant Removal by Coagulation and Related Process Combinations. J. Am. Water Work. Assoc. 1988, 80, 40-56. [CrossRef]

59. Kuzubova, L.I.; Morozov, S.V. Organic contaminant of drinking water. Ecology. World Lit. Rev. Ser. 1993, 1, 1-167.

60. Garcia-Costa, A.L.; Zazo, J.A.; Casas, J.A. Microwave-assisted catalytic wet peroxide oxidation: Energy optimization. Sep. Purif. Technol. 2019, 215, 62-69. [CrossRef]

61. Cheng, G.; Lin, J.; Lu, J.; Zhao, X.; Cai, Z.; Fu, J. Advanced Treatment of Pesticide-Containing Wastewater Using Fenton Reagent Enhanced by Microwave Electrodeless Ultraviolet. BioMed Res. Int. 2015, 2015, 1-8. [CrossRef] [PubMed]

62. Wang, N.; Sun, X.; Zhao, Q.; Wang, P. Treatment of polymer-flooding wastewater by a modified coal fly ash-catalysed Fentonlike process with microwave pre-enhancement: System parameters, kinetics, and proposed mechanism. Chem. Eng. J. 2021, 406, 126734. [CrossRef]

63. Lin, L.; Chen, J.; Xu, Z.; Yuan, S.; Cao, M.; Liu, H.; Lu, X. Removal of ammonia nitrogen in wastewater by microwave radiation: A pilot-scale study. J. Hazard. Mater. 2009, 168, 862-867. [CrossRef]

64. Ravera, M.; Buico, A.; Gosetti, F.; Cassino, C.; Musso, D.; Osella, D. Oxidative degradation of 1,5-naphthalenedisulfonic acid in aqueous solutions by microwave irradiation in the presence of $\mathrm{H}_{2} \mathrm{O}_{2}$. Chemosphere 2009, 74, 1309-1314. [CrossRef]

65. Jung, S.C. The microwave-assisted photo-catalytic degradation of organic dyes. Water Sci. Technol. 2011, 63, 1491-1498. [CrossRef] [PubMed]

66. Lee, Y.-C.; Lo, S.-L.; Chiueh, P.-T.; Chang, D.-G. Efficient decomposition of perfluorocarboxylic acids in aqueous solution using microwave-induced persulfate. Water Res. 2009, 43, 2811-2816. [CrossRef]

67. Han, D.-H.; Cha, S.-Y.; Yang, H.-Y. Improvement of oxidative decomposition of aqueous phenol by microwave irradiation in $\mathrm{UV} / \mathrm{H}_{2} \mathrm{O}_{2}$ process and kinetic study. Water Res. 2004, 38, 2782-2790. [CrossRef] [PubMed]

68. Ta, N.; Hong, J.; Liu, T.; Sun, C. Degradation of atrazine by microwave-assisted electrodeless discharge mercury lamp in aqueous solution. J. Hazard. Mater. 2006, 138, 187-194. [CrossRef]

69. Hong, J.; Sun, C.; Yang, S.-G.; Liu, Y.-Z. Photocatalytic degradation of methylene blue in $\mathrm{TiO}_{2}$ aqueous suspensions using microwave powered electrodeless discharge lamps. J. Hazard. Mater. 2006, 133, 162-166. [CrossRef] [PubMed]

70. Horikoshi, S.; Hidaka, H.; Serpone, N. Environmental remediation by an integrated microwave/UV illumination technique: VI. A simple modified domestic microwave oven integrating an electrodeless UV-Vis lamp to photodegrade environmental pollutants in aqueous media. J. Photochem. Photobiol. A Chem. 2004, 161, 221-225. [CrossRef]

71. Horikoshi, S.; Tokunaga, A.; Hidaka, H.; Serpone, N. Environmental remediation by an integrated microwave/UV illumination method: VII. Thermal/non-thermal effects in the microwave-assisted photocatalyzed mineralization of bisphenol-A. J. Photochem. Photobiol. A Chem. 2004, 162, 33-40. [CrossRef] 
72. Zhanqi, G.; Shaogui, Y.; Na, T.; Cheng, S. Microwave assisted rapid and complete degradation of atrazine using $\mathrm{TiO}_{2}$ nanotube photocatalyst suspensions. J. Hazard. Mater. 2007, 145, 424-430. [CrossRef]

73. Verma, P.; Samanta, S.K. Microwave-enhanced advanced oxidation processes for the degradation of dyes in water. Environ. Chem. Lett. 2018, 16, 969-1007. [CrossRef]

74. Zhang, X.; Wang, Y.; Li, G.; Qu, J. Oxidative decomposition of azo dye C.I. Acid Orange 7 (AO7) under microwave electrodeless lamp irradiation in the presence of $\mathrm{H}_{2} \mathrm{O}_{2}$. J. Hazard. Mater. 2006, 134, 183-189. [CrossRef]

75. Hong, J.; Ta, N.; Yang, S.-G.; Liu, Y.-Z.; Sun, C. Microwave-assisted direct photolysis of bromophenol blue using electrodeless discharge lamps. Desalination 2007, 214, 62-69. [CrossRef]

76. Wang, N.; Wang, P. Study and application status of microwave in organic wastewater treatment-A review. Chem. Eng. J. 2016, 283, 193-214. [CrossRef]

77. Ju, Y.; Yang, S.; Ding, Y.; Sun, C.; Gu, C.; He, Z.; Qin, C.; He, H.; Xu, B. Microwave-enhanced $\mathrm{H}_{2} \mathrm{O}_{2}$-based process for treating aqueous malachite green solutions: Intermediates and degradation mechanism. J. Hazard. Mater. 2009, 171, 123-132. [CrossRef]

78. Yang, S.; Wang, P.; Yang, X.; Wei, G.; Zhang, W.; Shan, L. A novel advanced oxidation process to degrade organic pollutants in wastewater: Microwave-activated persulfate oxidation. J. Environ. Sci. 2009, 21, 1175-1180. [CrossRef]

79. Zhang, X.; Li, G.; Wang, Y. Microwave assisted photocatalytic degradation of high concentration azo dye Reactive Brilliant Red X-3B with microwave electrodeless lamp as light source. Dye. Pigment. 2007, 74, 536-544. [CrossRef]

80. Anshuman, A.; Saremi-Yarahmadi, S.; Vaidhyanathan, B. Enhanced catalytic performance of reduced graphene oxide-TiO 2 hybrids for efficient water treatment using microwave irradiation. RSC Adv. 2018, 8, 7709-7715. [CrossRef]

81. Mishra, S.; Meda, V.; Dalai, A.K.; Headley, J.V.; Peru, K.M.; McMartin, D.W. Microwave treatment of naphthenic acids in water. J. Environ. Sci. Health Part A 2010, 45, 1240-1247. [CrossRef] [PubMed]

82. Evdokimov, I.N.; Novikov, M.A. Structural features of industrial water-crude oil emulsions. Microwave studies. Chem. Technol. Fuels Oils 2007, 43, 46-50. [CrossRef]

83. Kovaleva, L.A.; Zinnatullin, R.R.; Mullayanov, A.; Mavletov, M.V.; Blagochinnov, V.N. Microstructure evolution of water-oil emulsions in high-frequency and microwave electromagnetic fields. High Temp. 2013, 51, 870-872. [CrossRef]

84. Saifuddin, N.M.; Chua, K.H. Treatment of Oily Waste Water Emulsions from Metallurgical Industries Using Microwave Irradiation. Biotechnology 2006, 5, 308-314. [CrossRef]

85. Kuo, C.-H.; Lee, C.-L. Treatment of oil/water emulsions using seawater-assisted microwave irradiation. Sep. Purif. Technol. 2010, 74, 288-293. [CrossRef]

86. Saifuddin, N.M.; Hussein, R. Separation of Water from Very Stable Water-in-Oil Emulsion Using Microwave Radiation with Presence of Inorganic Salts. Int. J. Chem. 2014, 35, 1512-1521.

87. Abdurahman, N.; Yunus, R.; Azhari, N.; Said, N.; Hassan, Z. The Potential of Microwave Heating in Separating Water-in-Oil (w/o) Emulsions. Energy Procedia 2017, 138, 1023-1028. [CrossRef]

88. Akbari, S.; Nour, A.; Fayaz, F.; Halimi, M.; Nour, A. Analysis of Microwave Heating Process for Demulsification of Water-in-Crude Oil Emulsions. Aust. J. Basic Appl. Sci. 2016, 10, 1-10.

89. Basak, T. Role of resonances on microwave heating of oil-water emulsions. AIChE J. 2004, 50, 2659-2675. [CrossRef]

90. Saitov, R.I.; Abdeev, E.R.; Khasanova, A.F.; Abdeev, R.G.; Rukomoynikov, A.A. Development of Energy-Efficient Equipment and Technology for Environmentally Friendly Microwave Processing of Oil Sludge. Int. J. Eng. Adv. Technol. 2020, 9, $1683-1687$.

91. Lamble, K.J.; Hill, S.J. Microwave digestion procedures for environmental matrices. Analyst 1998, 123, 103-133. [CrossRef]

92. Kutseva, N.K.; Kryuchkova, S.L.; Pirogova, S.V.; Naumova, S.V.; Kryuchkov, V.A.; Chamaev, A.V. Microwave Sample Preparation in the Determination of Metals in Waste Water. J. Anal. Chem. 2000, 55, 1142-1147. [CrossRef]

93. Kütük, M.A.; Aksoy, M. A Case Study on Sewage Sludge Incineration Plant: Gaski. In Proceedings of the Second International Conference on Water, Energy and the Environment, Kusadas1, Turkey, 21-24 September 2013; pp. 1-6.

94. Blagojevic, V.; Sustersic, V.; Bozickovic, S.; Veselin, B.; Vanja, Š.; Siniša, B. Pyrolysis and gasification in the process of sewage sludge treatment. Zast. Mater. 2017, 58, 305-312. [CrossRef]

95. Donatello, S.; Cheeseman, C.R. Recycling and recovery routes for incinerated sewage sludge ash (ISSA): A review. Waste Manag. 2013, 33, 2328-2340. [CrossRef] [PubMed]

96. Khramenkov, S.V.; Pakhomov, A.N.; Khrenov, K.E.; Streltsov, S.A.; Khamidov, M.G.; Belov, N.A. Utilization of Biogas and Creation of Autonomous Sources of Power Supply at Treatment Facilities. Water Supply Sanit. Tech. 2010, 10-1, 48-53.

97. Fericelli, P.D. Comparison of Sludge Treatment by Gasification vs. Incineration. In Proceedings of the Ninth LACCEI Latin American and Caribbean Conference (LACCEI'2011), Medellín, Colombia, 3-5 August 2011; p. 10.

98. Danilovich, D.A. Crisis of competence in the design of wastewater treatment facilities. Best Available Technol. Water Supply Sanit. 2018, 4, 5-13.

99. Coelho, N.M.G.; Droste, R.L.; Kennedy, K.J. Evaluation of continuous mesophilic, thermophilic and temperature phased anaerobic digestion of microwaved activated sludge. Water Res. 2011, 45, 2822-2834. [CrossRef]

100. Hong, S.-M. Enhancement of Pathogen Destruction and Anaerobic Digestibility Using Microwaves. Ph.D. Thesis, University of Wisconsin, Madison, WI, USA, 2002.

101. Eskicioglu, C.; Kennedy, K.J.; Droste, R.L. Enhancement of batch waste activated sludge digestion by microwave pretreatment. Water Environ. Res. 2007, 79, 2304-2317. [CrossRef] 
102. Eskicioglu, C.; Droste, R.L.; Kennedy, K.J. Performance of Anaerobic Waste Activated Sludge Digesters after Microwave Pretreatment. Water Environ. Res. 2007, 79, 2265-2273. [CrossRef] [PubMed]

103. Toreci, I.; Kennedy, K.J.; Droste, R.L. Effect of High-Temperature Microwave Irradiation on Municipal Thickened Waste Activated Sludge Solubilization. In Proceedings of the 11th Conference on Process Integration, Modeling and Optimization for Energy Saving and Pollution Reduction (PRES), Prague, Czech Republic, 24-28 August 2008.

104. Toreci, I.; Kennedy, K.J.; Droste, R.L. Evaluation of continuous mesophilic anaerobic sludge digestion after high temperature microwave pretreatment. Water Res. 2009, 43, 1273-1284. [CrossRef] [PubMed]

105. Mehdizadeh, S.N.; Eskicioglu, C.; Bobowski, J.; Johnson, T. Conductive heating and microwave hydrolysis under identical heating profiles for advanced anaerobic digestion of municipal sludge. Water Res. 2013, 47, 5040-5051. [CrossRef] [PubMed]

106. Haranghy, L.; Kertesz, S.Z.; Vereb, G.; Laszlo, Z.S.; Vagvolgyi, A.; Jakoi, Z.; Czupy, I.; Hodur, C.; Rakhely, G.; Beszedes, S. Intensification of the biodegradation of wastewater sludge by microwave irradiation. Geosci. Eng. 2020, 8, 322-333. Available online: https: / www.researchgate.net/publication/346483507 (accessed on 3 May 2021).

107. Yanin, E.P. Domestic wastewater sludge burning (Problems and Methods). Resour. Sav. Technol. 2006, $24,3-29$.

108. Zaker, A.; Chen, Z.; Wang, X.; Zhang, Q. Microwave-assisted pyrolysis of sewage sludge: A review. Fuel Process. Technol. 2019, 187, 84-104. [CrossRef]

109. Menéndez, J.; Inguanzo, M.; Pis, J. Microwave-induced pyrolysis of sewage sludge. Water Res. 2002, 36, 3261-3264. [CrossRef]

110. Malyshkina, E.S.; Vyalkova, E.I.; Osipova, E.Y. Water Purification with Natural Sorbents. Vestn. Tomsk. Gos. arkhitekturnostroitel'nogo Univ. J. Constr. Arch. 2019, 21, 188-200. [CrossRef]

111. Bakhia, T.; Khamizov, R.K.; Bavizhev, M.D.; Konov, M.A. The effect of microwave treatment of clinoptilolite on its ion-exchange kinetic properties. Sorpt. Chromatogr. Process. 2016, 16, 803-812.

112. Berdonosov, S.S. Microwave chemistry. Soros Educ. J. 2001, 7, 32-38.

113. Bannova, E.A.; Kitaeva, N.K.; Merkov, S.M.; Muchkina, M.V.; Zaloznaya, E.P.; Martynov, P.N. Study of a method for obtaining a hydrophobic sorbent based on modified peat. Sorpt. Chromatogr. Process. 2013, 13, 60-68.

114. Danilov, O.S.; Mikheyev, V.A.; Moskalenko, T.V. Research of Electromagnetic Microwave Radiation Influence on the Solid Fuels. Izv. Samara Sci. Cent. Russ. Acad. Sci. 2011,13, 1264-1267.

115. Belchinskaya, L.I.; Khodosova, N.A.; Novikova, L.A. Effect of different mechanisms of heating of layered aluminosilicate on sorption processes Communication 1. Effect of preliminary thermal and electromagnetic (microwave) heating of montmorillonite on sorption of water. Sorption and chromatographic processes. Сорбционные ХроматографическиеПроцессы 2017, 17, 781-791. (In Russian) [CrossRef]

116. Faizal, A.M.; Kutty, S.R.M.; Ezechi, E.H. Removal of Oil from Water by Column Adsorption Method Using Microwave Incinerated Rice Husk Ash (MIRHA). InCIEC 2014 2015, 963-971. [CrossRef]

117. Myuller, R.F.; Ol'shanskaya, V.P.; Rumyantsev, A.I. Method of Regeneration of Sorbents by Non-Thermal Exposure to Ultra-HighFrequency Electromagnetic Radiation. Russian Patent RU2438774C1, 10 January 2012.

118. Yuen, F.K.; Hameed, B.H. Recent developments in the preparation and regeneration of activated carbons by microwaves. Adv. Colloid Interface Sci. 2009, 149, 19-27. [CrossRef]

119. Foo, K.Y.; Hameed, B.H. Microwave-assisted regeneration of activated carbon. Bioresour. Technol. 2012, 119, 234-240. [CrossRef] [PubMed]

120. Stenanov, S.F.; Ahmedova, O.O.; Soshimov, A.G. Sewage Treatment Installation. Russian Patent RU116851U1, 10 June 2012.

121. Gunich, S.V.; Valycheva, T.I. Method of Processing of Domestic and Industrial Wastes to Furnace Fuel and Hydrocarbon Substance and Device to This End. Russian Patent RU2552259C2, 10 June 2015.

122. Naumov, V.V.; Zdraevskij, D.A.; Glazunov, V.I.; Berezovskij, O.M. Method of Processing and Utilisation of Wastes. Russian Patent RU2573137C1, 10 January 2016.

123. Levin, E.V. Installation of Microwave Processing of Sewage Sludge. Russian Patent RU2582415C2, 27 April 2016.

124. Zemlyanova, M.V.; Vialkova, E.I.; Obukhov, L.V. Method for Treatment and Decontamination of Waste Water and Sediments Thereof, and Device for Method Implementing. Russian Patent RU2693783C1, 4 July 2019.

125. Kovalev, D.A.; Kovalev, A.A.; Sobchenko, Y.A. Method and Plant for Anaerobic Processing of Liquid Organic Wastes. Russian Patent RU2687415C1, 13 May 2019.

126. Bogdanov, A.V.; Perevalova, N.I.; Migunov, M.I.; Tarasevich, S.A.; Khrushchev, V.V.; Grekhov, I.V.; Kovaleva, L.A.; Zinnatullin, R.R.; Sultanguzhin, R.F.; Gabdrafikov, A.F. System and Method for Electromagnetic Phase Separation of Water-Oil Emulsion. Russian Patent RU2710181C1, 24 December 2019.

127. Sivokon, V.N.; Tishechkin, N.N.; Klyushnik, A.A.; Dyatlov, A.V.; Smirnov, A.A. Wastewater Treatment Plant by Irradiation with Ultrahigh Frequency Waves and Ultraviolet Light. Russian Patent RU193171U1, 15 October 2019.

128. Zobnin, B.B.; Kochetkov, V.V.; Vozhegov, A.V.; Semiachkov, A.I.; Ponomarev, O.P.; Matevosian, M.B. Method of Purifying Acid Mine Water and Mobile Process Complex for Implementation Thereof. Russian Patent RU2739259C1, 22 December 2020. 